\title{
Computational models reveal how chloride dynamics determine the optimal distribution of inhibitory synapses to minimise dendritic excitability
}

\author{
Christopher Brian Currin ${ }^{1}$ and Joseph Valentino Raimondo ${ }^{1}$ \\ ${ }^{1}$ Division of Cell Biology, Department of Human Biology, Neuroscience Institute and Institute \\ of Infectious Disease and Molecular Medicine, Faculty of Health Sciences, University of \\ Cape Town, Cape Town, South Africa
}

\begin{abstract}
Many neurons in the mammalian central nervous system have complex dendritic arborisations and active dendritic conductances that enable these cells to perform sophisticated computations. How dendritically targeted inhibition affects local dendritic excitability is not fully understood. Here we use computational models of branched dendrites to investigate where GABAergic synapses should be placed to minimise dendritic excitability over time. To do so, we formulate a metric we term the "Inhibitory Level" (IL), which quantifies the effectiveness of synaptic inhibition for reducing the depolarising effect of nearby excitatory input. GABAergic synaptic inhibition is dependent on the reversal potential for GABAA receptors (EGABA), which is primarily set by the transmembrane chloride ion ( $\mathrm{Cl}$ ) concentration gradient. We, therefore, investigated how variable EGABA and dynamic chloride affects dendritic inhibition. We found that the inhibitory effectiveness of dendritic GABAergic synapses accumulates at an encircled branch junction. The extent of inhibitory accumulation is dependent on the number of branches and location of synapses but is independent of EGABA. This accumulation occurs even for very distally placed inhibitory synapses when they are hyperpolarising - but not when they are shunting. When accounting for $\mathrm{Cl}^{-}$fluxes and dynamics in $\mathrm{Cl}^{-}$concentration, we observed that $\mathrm{Cl}^{-}$loading is detrimental to inhibitory effectiveness. This enabled us to determine the most inhibitory distribution of GABAergic synapses which is close to - but not at - a shared branch junction. This distribution balances a trade-off between a stronger combined inhibitory influence when synapses closely encircle a branch junction with the deleterious effects of increased $\mathrm{Cl}^{-}$loading that occurs when inhibitory synapses are co-located.
\end{abstract}

\section{ACKNOWLEDGEMENTS:}

The authors would like to thank Albert Gidon for our discussions on the shunt level, and Kira Dusterwald for their input on the manuscript. CBC is supported by the German Deutscher Akademischer Austauschdienst (DAAD, https://www.daad.de/), the South African (SA) National Research Foundation (NRF, https://www.nrf.ac.za), and the University of Cape Town (UCT, https://www.uct.ac.za). JVR is supported the National Research Foundation of South Africa, a Wellcome Trust Seed Award (214042/Z/18/Z), the South African Medical Research Council and by the FLAIR Fellowship Programme (FLRIR1\190829): a partnership between the African Academy of Sciences and the Royal Society funded by the UK Government's Global Challenges Research Fund. 
bioRxiv preprint doi: https://doi.org/10.1101/2021.12.07.471404; this version posted December 8,2021 . The copyright holder for this preprint (which was not certified by peer review) is the author/funder, who has granted bioRxiv a license to display the preprint in perpetuity. It is made available under aCC-BY 4.0 International license.

Introduction

\section{INTRODUCTION}

A typical layer $2 / 3$ cortical pyramidal neuron can have thousands of synaptic sites from hundreds to thousands of neurons [1-3]. A neuron's ability to integrate synaptic input over multiple time scales and physical spatial domains is possible due to the physical structure and electrochemical properties of its dendrites [4-6]. Dendrites enable neurons to perform a broad array of possible computations [7]. Experimental and theoretical results over the last few decades have shifted the characterisation of dendrites as simply the input domain of neuron, to a neuronal feature with rich computational complexity [8-13].

The theoretical understanding of signal propagation in dendrites was established by several seminal studies [14-19]. This understanding was grounded in the assumption that dendrites are passive. We now know that they also possess active properties driven by NMDA, voltagegated calcium $\left(\mathrm{Ca}^{2+}\right)$, and voltage-gated sodium $\left(\mathrm{Na}^{+}\right)$channels [20], which adds to the complexity of dendritic processing [6,21]. The traditional view of inhibition in dendrites has focused on its effects at the soma. That is, how does dendritic inhibition change the excitatory current that reaches the soma, which affects the activation of non-linear processes there or at the axon initial segment. Due to the experimental challenges involved in recording from dendrites, the somato-centric view has been more prevalent to-date. In contrast to this somato-centric viewpoint, it has now become clear that many neurons possess dendrites with non-linear conductances (e.g. NMDA receptors, voltage-gated $\mathrm{Ca}^{2+}$ and $\mathrm{Na}^{+}$channels). It is now thought that dendritic branches could act as individual non-linear integration zones meaning that single neurons could represent the biological equivalent of multi-level artificial neuronal networks $[13,22,23]$. This points to the importance of also considering a dendrocentric viewpoint, i.e. how does dendritic inhibition control local dendritic excitability?

In this vein, a recent computational study found that dendritic inhibition can lessen dendritic excitability more effectively when inhibitory synapses are located farther from the soma than an excitatory source, "off-path", as opposed to being positioned between the soma and excitation, "on-path" [21]. Because of the dendro-centric viewpoint of this finding, it is not contradictory but rather complementary with studies that show that "on-path" inhibition is more effective at preventing action potential generation at the soma [16,24-26].

To date, investigations into inhibition's dampening effect on dendritic excitability have paid little attention to the inhibitory reversal potential [21], or how this could change over time with continued synaptic drive $[26,27]$. However, fast dendritic inhibition is predominantly mediated by type $A$-aminobutyric acid receptors $\left(G A B A_{A} R s\right)$, which are primarily permeable to chloride ions $\left(\mathrm{Cl}^{-}\right)$[28]. As a result, the inhibitory reversal potential depends on the transmembrane $\mathrm{Cl}^{-}$ gradient, which is a dynamic variable that can change depending on the balance of $\mathrm{Cl}^{-}$ion fluxes into and out of dendritic processes $[26,29]$. Previous experimental and modelling studies have shown that because of their small volume, dendrites are particularly susceptible to activity-dependent $\mathrm{Cl}^{-}$accumulation and shifts in the inhibitory reversal potential (EGABA) [27,30-33]. However, how $\mathrm{Cl}^{-}$dynamics and different inhibitory reversal potentials affect dendritic inhibition's ability to control dendritic excitability has not previously been investigated. We used computational models built using the NEURON modelling framework to answer the important question, "Where should inhibitory synapses be placed within a branched dendrite to minimise dendritic excitability over time?"

We first extended a metric established by Gidon and Segev [21], which allowed us to quantify the effectiveness of synaptic inhibition of different reversal potentials (EGABA) on nearby 
bioRxiv preprint doi: https://doi.org/10.1101/2021.12.07.471404; this version posted December 8, 2021. The copyright holder for this preprint (which was not certified by peer review) is the author/funder, who has granted bioRxiv a license to display the preprint in perpetuity. It is made available under aCC-BY 4.0 International license.

Methods

dendritic excitatory input. We termed this metric the "Inhibitory Level" (IL). Second, we employed this metric to demonstrate that inhibition accumulates at an encircled branch junction. This inhibitory accumulation is dependent on the number of branches and location of synapses but is independent of EGABA. Third, we find that hyperpolarizing inhibition accumulates at branch points even for very distally placed synapses, but this is not the case for shunting inhibition, where there is an optimal distance from a branch junction where synapses should be located in order to maximise inhibitory accumulation. Fourth, we find that adding more inhibitory synapses increases absolute dendritic inhibition, but that the extent of inhibitory accumulation across a tree is maintained. Fifth, by accounting for $\mathrm{Cl}^{-}$dynamics we demonstrate that the $\mathrm{Cl}^{-}$loading that occurs during continuous inhibitory synaptic input erodes the effectiveness of absolute dendritic inhibition. However, this does not reduce the ability for dendritic inhibition to accumulate. As a result, we find that the optimal placement of inhibitory synapses to maximise dendritic inhibitory effectiveness is close to, but not precisely at, a shared branch junction. This placement balances a trade-off between enhanced inhibitory accumulation when inhibitory synapses encircle a branch junction with the deleterious, cumulative effects of $\mathrm{Cl}^{-}$loading when synapses are close together.

\section{METHODS}

Multiple synaptic inputs, together with passive channels throughout the neuron and any current applied externally, caused a change in membrane voltage according to:

$$
C_{m} \frac{d V_{m}}{d t}=-g_{\text {pas }}\left(V_{m}(t)-V_{\text {rest }}\right)-I_{\text {syn }}(t)+I_{\text {ext }}(t)
$$

where $C_{m}$ is the membrane capacitance $(1 \mu \mathrm{F}), V_{m}$ is the membrane potential, $g_{\text {pas }}$ is the leak channel's conductance $(0.05 \mathrm{mS}$, the inverse of the membrane input resistance, $20 \mathrm{M} \Omega), V_{\text {rest }}$ is the resting membrane potential $(-65 \mathrm{mV}), I_{\text {syn }}$ is the sum of synaptic currents, and $l_{\text {ext }}$ is externally applied current $(0.001 \mathrm{nA})$. See Table 1 for abbreviations, constants, and parameter values.

A synapse's input (current, $I_{\text {syn }}$ ) was defined according to its activation (conductance, $g_{\text {syn }}$ ) and its driving force (the difference between $V_{m}$ and the synapse's reversal potential, $E_{\text {syn }}$ ) to drive a current into or out of the neuron:

$$
I_{\text {syn }}=g_{\text {syn }} \underbrace{\left(V_{m}-E_{\text {syn }}\right)}_{\text {driving force }}
$$

Where each term depended on time, $t$. Synaptic input depended on the flow of ions across the neuronal membrane, through the synaptic channel, according to their electrochemical gradients, $E_{\text {syn. }}$ Synaptic conductances reduce the membrane input resistance, which can elicit "shunting inhibition" in synapses when $\mathrm{V}_{\mathrm{m}}=\mathrm{E}_{\text {syn, }}$, and thereby act as a 'sink' for current travelling along its path. For convenience, we defined the difference between the resting membrane potential $\left(V_{\text {rest }}\right)$ and the reversal potential for an inhibitory synapse (EGABA) as

$$
\nabla E_{G A B A}=V_{\text {rest }}-E_{G A B A}
$$

Note that although this appears similar to the definition for driving force, which changes with $V_{m}$ and EGABA, $\nabla E G A B A$ only changes with EGABA. Inhibitory synapses were, therefore, classified as shunting $\nabla E G A B A=0 \mathrm{mV}$ ) or hyperpolarising $(\nabla E G A B A<0 \mathrm{mV})$. 
Methods

The effects of inhibitory synaptic input are not just local changes in $V_{m}$, but also the propagation of voltage, given by the cable equation [34], and the spread of lowered input resistance along a neuron [21]. We captured both of these effects in something we term the "Inhibitory Level" (IL): the impact that an inhibitory synapse at a location i would have on an excitatory input at location $\mathrm{d}$. The IL was defined as

$$
I L_{\mathrm{d}}^{\mathrm{i}}=\frac{V_{\mathrm{d}}-V_{\mathrm{d}}^{\mathrm{i}}}{V_{\mathrm{d}}}
$$

where $V_{d}$ is the time integral of voltage deflection at location $d$ with no inhibition and $V_{d}{ }^{i}$ is the time integral of voltage deflection at location d with inhibition at location i. More explicitly,

$$
V_{\mathrm{d}}=\int_{t}^{t+\Delta t} V_{m}(t)-V_{\text {rest }} d t
$$

where $\Delta \mathrm{t}$ is the time window of integration (5 ms in Figure 1, $50 \mathrm{~ms}$ otherwise).

Although this formulation captures transient inputs, simulations had a constant injected current, $l_{\text {ext }}=0.001 \mathrm{nA}$, as the source of excitation (moved to different locations $\mathrm{d}$ ), and inhibitory synapse(s) were modelled as persistent conductance-fluctuating current, "gclamp", as in [24-26]. Gclamp inhibitory synapses were selectively permeable to both $\mathrm{Cl}^{-}$and $\mathrm{HCO}_{3}{ }^{-}$ ions (4:1 ratio), with currents calculated according to

$$
\begin{aligned}
I_{G A B A_{A}} & =I_{C l^{-}}+I_{H_{C O}^{-}} \\
I_{C l^{-}} & =\frac{4}{5} g_{G A B A}\left(V_{m}-E_{C l^{-}}\right) \\
I_{\mathrm{HCO}_{3}^{-}} & =\frac{1}{5} g_{G A B A}\left(V_{m}-E_{\mathrm{HCO}_{3}^{-}}\right)
\end{aligned}
$$

where the reversal potential for chloride $\left(\mathrm{ECl}^{-}\right)$was updated, where applicable, throughout the simulation using the Nernst equation, $E_{\mathrm{Cl}^{-}}=\frac{R \cdot T}{F} \ln \left(\frac{\left[\mathrm{Cl}^{-}\right]_{i}}{\left[\mathrm{Cl}^{-}\right]_{o}}\right)$. The reversal potential for $\mathrm{HCO}_{3}{ }^{-}$ was held constant (-18 $\mathrm{mV})$, and EGABA calculated as $E_{G A B A}=\frac{4}{5} E_{C l^{-}}+\frac{1}{5} E_{\mathrm{HCO}_{3}^{-}}$. The gclamp mean conductance, $\langle\mathrm{g}\rangle$, was $0.001 \mu \mathrm{S}$, with a standard deviation of $0.1 \times\langle\mathrm{g}\rangle$.

Transmembrane $\mathrm{Cl}^{-}$fluxes due to $\mathrm{Cl}^{-}$currents through $\mathrm{GABA}_{A} \mathrm{Rs}, \mathrm{KCC} 2$ co-transporter, as well as changes due to longitudinal diffusion, as modelled in [26], were calculated as

$$
\frac{d\left[C l^{-}\right]_{i}}{d t}=\frac{I_{C l^{-}}}{F \cdot V o l}+P_{K C C 2}\left(\left[K^{+}\right]_{i} \cdot\left[C l^{-}\right]_{i}-\left[K^{+}\right]_{o} \cdot\left[C l^{-}\right]_{o}\right)+D_{C l^{-}} \frac{d\left[C l^{-}\right]_{i}}{d x}
$$

where $P_{K c c 2}$ is the "pump strength" of chloride extrusion $\left(1.9297 \times 10^{-5} \mathrm{~mA} /\left(\mathrm{mM}^{2} \cdot \mathrm{cm}^{2}\right), \mathrm{K}^{+}\right.$is the potassium ion, $D_{C l^{-}}$is the diffusion coefficient for chloride in water $\left(2.03 \mu \mathrm{m}^{2} \mathrm{~ms}^{-1}\right), \mathrm{F}$ is Faraday's constant, $\mathrm{Vol}$ is the volume of the compartment, and $\mathrm{x}$ is the longitudinal distance between the midpoint of compartments.

The impact of time-varying EGABA (due to changes in $\left[\mathrm{Cl}^{-}\right]_{i}$ ) on the IL was implicitly captured by Eq. 1. Unless otherwise indicated, $\mathrm{Cl}^{-}$was static and EGABA was constant throughout any simulation. 
bioRxiv preprint doi: https://doi.org/10.1101/2021.12.07.471404; this version posted December 8, 2021. The copyright holder for this preprint (which was not certified by peer review) is the author/funder, who has granted bioRxiv a license to display the preprint in perpetuity. It is made available under aCC-BY 4.0 International license.

Results

Distance was expressed in units of electrotonic distance $(X)$ such that $1.0 \mathrm{X}$ was one space constant $(\lambda)$. The space constant is a measure of how far voltage will travel within a neuronal compartment as it attenuates with distance [35], and is defined according to

$$
1.0 \mathrm{X}=\lambda=\sqrt{\frac{r R_{m}}{2 R_{a}}}
$$

where $r$ is the radius of the dendrite, $R_{m}$ is the membrane resistivity, and $R_{a}$ is the axial resistivity. For a radius of $0.5 \mu \mathrm{m}, R_{m}$ of $20 \mathrm{M} \Omega \cdot \mathrm{cm}^{2}$, and $R_{a}$ of $0.1 \mathrm{M} \Omega \cdot \mathrm{cm}$, the branch length was $707 \mu \mathrm{m}$.

Simulations were performed with the NEURON modelling framework using the Python interface [36,37]. Full code is available online at https://github.com/ChrisCurrin/chloridedynamics-and-dendrites.

\section{RESULTS}

Inhibitory Level as a metric to assess the effect of dendritic inhibition on dendritic excitability

We defined Inhibitory Level (IL) as an extension of the "shunt level" established by Gidon and Segev [21] to account for voltage-dependent effects of hyperpolarising inhibitory synapses (see Eq. 1 above). The IL measures the influence of an inhibitory synapse at location i on an excitatory input at location d. To determine a dendrite's IL for a fixed i (e.g. at $0.4 \mathrm{X}$ ), d was varied along the length of the dendrite (Figure 1A). The steady-state IL for a shunting synapse (that is, $\nabla E G A B A=0 \mathrm{mV}$ ) on a single branch was highest at the site of the inhibitory synapse, as found previously [21].

Figure 1B shows the time evolution of $\mathrm{IL}_{d}=0.3$ (left, orange circles) and $\mathrm{IL}_{d}=0.7$ (right, red circles) calculated from $V_{\mathrm{d}}$ (solid grey area) and $V_{\mathrm{d}}^{\mathrm{i}}$ (striped grey area). In both cases, the inhibitory synapse location i was $0.4 \mathrm{X}$. Within $150 \mathrm{~ms}$, IL reached its steady-state value. Because the neuronal membrane is a capacitor and IL is calculated from $V_{m}$, the IL was taken at $150 \mathrm{~ms}$ unless otherwise stated.

The IL represents a change in membrane voltage deflection caused by inhibition. The IL captures the spatial impact of an inhibitory synapse from both its conductance component, measured as a change of input resistance, as well as its inhibitory post-synaptic potential (IPSP). The IL is, therefore, equivalently.

$$
I L_{\mathrm{d}}^{\mathrm{i}}=\frac{R_{\mathrm{d}}-R_{\mathrm{d}}^{\mathrm{i}}}{R_{\mathrm{d}}}-\frac{\text { IPSP }}{V_{\mathrm{d}}}
$$

where $R_{d}$ is the input resistance at location $d$ with no inhibition, $R_{d}{ }_{d}$ is the input resistance at location $\mathrm{d}$ with inhibition at location $\mathrm{i}$, and IPSP is the inhibitory post-synaptic potential. The IPSP is zero when a synapse is shunting - its reversal potential is the same as the $V_{\text {rest }}$ (VEGABA $=0 \mathrm{mV}$ ), as in Figure 1. In fact, the IL for shunting synapses can be analytically calculated, as in Gidon and Segev [21], by determining $\Delta \mathrm{R}_{\mathrm{d}}$, at the input location $(\mathrm{d}=\mathrm{i}), \Delta R_{\mathrm{d}}=$ $\frac{g_{\mathrm{i}} R_{\mathrm{i}, \mathrm{d}}^{2}}{1+g_{\mathrm{i}} R_{\mathrm{i}}}$ [38], and the transfer resistance from i to $\mathrm{d}, R_{\mathrm{i}, \mathrm{d}}=R_{\mathrm{i}} A_{\mathrm{i}, \mathrm{d}}=R_{\mathrm{d}} A_{\mathrm{d}, \mathrm{i}}$. Together, 
Results

$$
\begin{aligned}
I L_{\mathrm{d}}^{\mathrm{i}} & =\frac{\frac{g_{\mathrm{i}} R_{\mathrm{i}, \mathrm{d}}^{2}}{1+g_{\mathrm{i}} R_{\mathrm{i}}}}{R_{\mathrm{d}}} \\
I L_{\mathrm{d}}^{\mathrm{i}} & =\frac{\frac{g_{\mathrm{i}} R_{\mathrm{i}} A_{\mathrm{i}, \mathrm{d}} R_{\mathrm{d}} A_{\mathrm{d}, \mathrm{i}}}{1+g_{\mathrm{i}} R_{\mathrm{i}}}}{R_{\mathrm{d}}} \\
I L_{\mathrm{d}}^{\mathrm{i}} & =\left[\frac{g_{\mathrm{i}} R_{\mathrm{i}}}{1+g_{\mathrm{i}} R_{\mathrm{i}}}\right] A_{\mathrm{i}, \mathrm{d}} A_{\mathrm{d}, \mathrm{i}}
\end{aligned}
$$

where $g_{i}$ is the conductance of the inhibitory synapse at location $i, R_{i}$ is the input resistance of the neuron at location $i$, and $A_{i, d}$ is the voltage attenuation from location $i$ to $d$ or vice versa.

The three methods to calculate IL (Eqs. 1, 2, 3) for shunting synapses are equivalent (Figure 1C). However, Eq. 3 can be calculated analytically, Eq. 2 can be computed semi-analytically using NEURON to record $R_{d}$, but Eq. 1 needs to be evaluated numerically and taken at the steady-state. Eq. 1, however, has two advantages: it works for time-varying input, and it captures both conductance and IPSP effects of inhibition, which is an integral component of hyperpolarising synapses. We therefore used Eq. 1 for calculating the IL for the remainder of this study.

Dendritic inhibition combines to suppress dendritic excitability at branch junctions.

Using the IL metric, we sought to confirm the finding that inhibitory synapses on multiple branches of a dendritic tree combine so that their cumulative inhibitory effect at a shared dendritic branch junction is greater than at the site of each inhibitory synapse, as demonstrated for the case of shunting inhibition [21]. We found that the functional impact of the inhibitory synapse on an excitatory source, as defined by the Inhibitory Level (IL), was maximised at the junction of a tree with a sufficient number of branches ( $\geq 4)$; with each branch having a single synapse at a consistent location (Figure 2). This was the case for both shunting inhibition (Figure 2A) and hyperpolarizing inhibition (Figure 2B).

Given a shunting inhibitory synapse on each branch (at $\mathrm{i}=0.2 \mathrm{X}$ ), increasing the number of branches decreased the individual influence of each synapse at its own location, while maintaining the same IL at the tree's junction (Figure 2Av). The IL for a low number of branches $(<4)$ was, therefore, highest at the site of the shunting synapse $\left(I L_{d=i}\right.$; Figure $2 A i$ and Figure 2Aii). However, once trees with 4 branches (Figure 2Aiii) or higher (Figure 2Aiv) were considered, then the IL at the junction was higher than at the shunting synapse. This was consistent with the findings of [21]. Also, IL at the junction $\left(\mathrm{IL}_{0}\right)$ for shunting inhibition remained stable $(\approx 0.4)$ for each tree independent of the number of branches. In contrast, for inhibitory synapses with hyperpolarizing reversal potentials ( $\mathrm{EEGABA}=-1 \mathrm{mV}$, Figure $2 \mathrm{~B}$ and $\nabla E G A B A=-2 \mathrm{mV}$, Figure $2 \mathrm{C}$ ), IL increased both at the synaptic location, $\mathrm{IL}_{\mathrm{d}=\mathrm{i}}$, and at the shared branch junction, $\mathrm{IL}_{0}$, for increasing numbers of branches (Figure $2 \mathrm{~B}$ ). More generally for hyperpolarizing inhibition, IL at each $\mathrm{d}$ increased with more branches and synapses.

Next, we sought to quantify how much IL (inhibitory effectiveness) accumulated at the shared branch junction relative to the IL at the location of the inhibitory synapse. To do so, we created a metric which we termed the "Accumulation Index" (Accldx) formulated as

$$
\text { AccIdx }=\frac{I L_{0}}{I L_{\mathrm{i}}}
$$


bioRxiv preprint doi: https://doi.org/10.1101/2021.12.07.471404; this version posted December $8,2021$. The copyright holder for this preprint (which was not certified by peer review) is the author/funder, who has granted bioRxiv a license to display the preprint in perpetuity. It is made available under aCC-BY 4.0 International license.

Results

where the inhibitory synapse location i was typically $0.2 \mathrm{X}$, as shown in Figure $2 \mathrm{C}$ inset. The Accldx can be intuitively understood as a relative view of dendritic inhibition; specifically, how much more inhibitory the GABAergic synapse is at the junction compared to its insertion location at $\mathrm{i}$.

To understand the influence of reversal potential on the accumulation of inhibitory effectiveness at a dendritic junction, the Accldx was investigated as a function of the number of branches and inhibitory reversal potential (Figure 2D). When a dendritic tree had more branches (with each having an inhibitory synapse), the Accldx increased linearly for the case where inhibition was hyperpolarizing and sub-linearly when inhibition was shunting. Interestingly, the relative amount of IL accumulation at a junction for a given number of branches was approximately the same regardless of reversal potential when EGABA was hyperpolarising.

In summary, while IL accumulated more at any junction with more negative inhibitory reversal potentials, the relative $\mathrm{IL}$ at the junction compared to the $\mathrm{IL}$ at the synapse itself (Accldx) stayed consistent. That is, a more negative reversal potential (with the same EGABA at every GABAergic synapse) increased IL at both the synapse and junction by the same proportion. Increasing the number of branches caused a greater accumulation of $\mathrm{IL}$ at the junction.

Increasing branch occupancy with inhibitory synapses enhances Inhibitory Level at the junction, but complete branch occupancy saturates the relative accumulation of inhibition.

To investigate the contribution of each synapse to the overall IL (how much a subset of inhibitory synapses suppresses the excitatory current at any particular location in the dendritic tree), the number of inhibitory synapses was varied while the number of branches stayed the same.

As the "effective number of branches" (the percentage of branches which have synapses) was increased, the IL also increased at both the synapse and junction (Figure 3). Figure $3 \mathrm{~A}$ and $\mathrm{B}$ demonstrates a dendrite with 4 branches and a varying number of inhibitory synapses $(\nabla E G A B A=0 \mathrm{mV})$. Although having 1 synapse on 4 branches ( $25 \%$ effective number of branches, Figure $3 \mathrm{Ai}$ and Figure $3 \mathrm{~B}$, thinnest green line) had a strong $\mathrm{IL}$ at the inhibitory synapses' branch, the IL attenuation was rapid. That is, the other "silent" or "unoccupied" branches were minimally influenced by the inhibitory synapse.

When the total number of synapses on branches was increased (50\% effective number of branches, Figure 3Aii and Figure 3B, thin green line), the branches with inhibitory synapses began to benefit each other mutually and had an increased IL. The combined effect of inhibitory synapses strongly influenced the $I L$ at the synapses themselves $\left(I L_{d=i}\right)$, the $I L$ at the junction $\left(\mathrm{I} \mathrm{L}_{0}\right)$, with the combinatory effect spilling over into the "silent" branches. At $100 \%$ effective number of synapses, the results were the same as before (Figure 3Aiii and Figure 3B medium green line). When each branch had 2 synapses per location (each at $i=0.2,200$ $\%$ effective number of synapses, Figure 3Aiv and Figure 3B thickest green line), the IL further increased along the dendrites. The same general pattern was evident for different numbers of branches (Figure 3C) and $\nabla E G A B A s$ (Figure 3D). In addition, when some branches had more synapses than others (e.g. $150 \%$ effective number of synapses), the $\mathrm{IL}_{0}$ was naturally shared between them, but the $\mathrm{IL}_{\mathrm{d}=\mathrm{i}}$ differed. This led to cases where the Accldx for branches with 
bioRxiv preprint doi: https://doi.org/10.1101/2021.12.07.471404; this version posted December 8,2021 . The copyright holder for this preprint (which was not certified by peer review) is the author/funder, who has granted bioRxiv a license to display the preprint in perpetuity. It is made available under aCC-BY 4.0 International license.

Results

fewer synapses were greater than branches with more synapses, yet the branches with more synapses had the greater IL (see Figure $3 \mathrm{~F}$ inset).

When inhibitory synapses continued to be added, their added inhibitory benefit diminished (Figure 3E). Although there was only saturation in $\mathrm{IL}_{0}$ for a large effective number of synapses (Figure 3E, $400 \%$ ), the Accldx reached its peak at $100 \%$ effective number of synapses regardless of the number of branches or $\nabla E G A B A$. This maximal value was reached every multiple of $100 \%$, when every branch had the same number of synapses, but only when $\nabla E G A B A<0 \mathrm{mV}$. In contrast for $\nabla E G A B A=0 \mathrm{mV}$, Accldx reached its global max at $100 \%$ and lower local max values for every subsequent multiple of $100 \%$. Interestingly, $100 \%$ for four branches and $50 \%$ for eight branches have the same number of synapses (4) but the Accldx is greater for eight branches when $\nabla E G A B A<0$. This result echoed the previous finding that more branches enhance the Accldx when $\nabla E G A B A<0$.

For dendrites with an unequal number of synapses per branch (e.g. $150 \%$ ), the Accldx was sub-maximal for branches with extra synapses (Figure 3F, main panel and inset), while the Accldx continued to increase for those branches with fewer synapses. The branches with more synapses increased the IL along the dendrite, including at the junction, $\mathrm{IL}$. The branches without synapses had a larger $I L_{0}$ than their own $I L_{d=i}$, while the branches with synapses had a smaller $\mathrm{IL}_{0}$ than their own $\mathrm{IL}_{\mathrm{d}=\mathrm{i}}$. Regardless, the difference in Accldx between branches with and without extra synapses is diminished as the effective number of branches increases (Figure 3F, inset). The sharing of a junction for multiple branches with a mixed number of synapses, therefore, benefited some branches more than others in terms of Accldx. Collectively these results show how differential occupation of branches with inhibitory synapses cumulatively affects local dendritic inhibitory efficacy.

\section{The location and distribution of inhibitory synapses determine how inhibition accumulates at} a branch junction.

The simulations presented thus far had kept the inhibitory synapses at a constant location relative to the branch junction. Furthermore, the distribution of inhibitory synapses had been consistent across the dendritic tree such that each synapse was at the same distance from the junction ("Tree" distribution). Therefore, we next explored how varying the location and distribution of inhibitory synapses on a branch affected the Inhibitory Level.

To do so, the IL was investigated for different inhibitory synapse locations, i, but where all synapses were placed an equal electrotonic distance from the branches' junction. For a dendritic arbour of 4 branches, shunting inhibitory synapses typically had their maximal IL at the synaptic site itself (regardless of distance from the junction), as demonstrated by example morphologies (Figure 4A, top row, $\nabla E G A B A=0 \mathrm{mV}$ ). In contrast, hyperpolarising inhibitory synapses had their maximal IL at the junction regardless of synapse location (Figure 4A, bottom row, $\nabla E G A B A=-2 \mathrm{mV}$ ). Hyperpolarising inhibitory synapses, therefore more effectively produced cumulative inhibition at sites distal from the synapse locations.

When comparing inhibitory synapse locations for a dendrite with 4 branches, IL at the hyperpolarising inhibitory synapse location $\left(I \mathrm{~L}_{\mathrm{d}=\mathrm{i}}\right)$ increases with proximity to the junction (Figure $4 \mathrm{~B}$, bottom). In contrast, $\mathrm{IL}_{\mathrm{d}=\mathrm{i}}$ for a shunting inhibitory synapse is greatest at the junction but weakest near the middle of the branches (Figure 4B, top). Shunting synapses benefitted from branches' terminals by constraining the input resistance attenuation. When 
bioRxiv preprint doi: https://doi.org/10.1101/2021.12.07.471404; this version posted December $8,2021$. The copyright holder for this preprint (which was not certified by peer review) is the author/funder, who has granted bioRxiv a license to display the preprint in perpetuity. It is made available under aCC-BY 4.0 International license.

Results

voltage attenuation was also a factor, as in hyperpolarising synapses, then the constrained input resistance was dwarfed by the influence of voltage spread.

As suggested by Figure 4A and Figure 4B, the Accldx increased with more distal synapse locations when $\nabla E G A B A=-2 \mathrm{mV}$. In contrast, the Accldx for $\nabla E G A B A=0 \mathrm{mV}$ peaked at $\mathrm{i}=$ $0.2 \times$ (Figure 4C). Both of these patterns were applicable for more than 4 branches but not less (Figure 4D). The case for 1 and 2 branches confirmed that these properties only hold once a branching threshold has been reached, which agreed with results from Figure 2D.

To investigate the non-linear effects of synaptic distributions, the "Tree" distribution for 4 branches was compared to a case where all synapses were evenly distributed on a single branch, "Branch", and a case where all the synapses were concentrated at a single location on a single branch, "Focal" (Figure 4E). For $\nabla E G A B A=-2 \mathrm{mV}$, the maximum IL of the dendritic arbour was different for each distribution. The "Tree" distribution produced the highest IL at the junction $(X=0)$. The "Focal" distribution predictably had the highest IL at the site of all the inhibitory synapses $(X=0.2)$, yet interestingly this was still not higher than the IL at the junction produced by the "Tree" distribution. The "Branch" distribution had a broadly raised IL over most of the branch (Figure 4F). The synaptic distributions of inhibitory synapses, therefore, showed different trade-offs in suppressing excitatory input (Figure 4F).

The "Tree" distribution was effective at suppressing the junction the best, which meant inhibitory synapses could be on separate branches a fair distance from the source of depolarisation and yet strongly impacted excitatory current that travelled through the dendrites (Figure 4E and F, green and also Figure 2B). However, the suppression of excitatory input farther along the branch (X closer to 1 ) would be weaker. Extending this to a more realistic pyramidal neuron morphology with a large amount of distal excitatory input and primarily proximal inhibitory input [39], GABA $R$ synapses on the proximal dendrites can still affect the main trunk even if they are on branches and not directly targeted on the trunk.

The "Branch" distribution had a more uniform IL across its targeted dendrite, while the remaining branches had depressed IL (Figure 4E and F, lilac). This distribution would be beneficial if the excitatory source was itself spread on that branch. Finally, the "Focal" distribution would maximally target an excitatory source at the same location, but the rest of the dendrite would be left susceptible. The branch selectivity of the "Branch" and "Focal" distributions, therefore, trade-off their gains for weaker ILs on their silent branches (Figure 4F, lighter colours). A neuron's dendrite might use several inhibitory distribution strategies that change over time in response to activity.

\section{Inhibitory Level is strongly influenced by dynamic chloride over time}

Inhibitory current not only depends on a neurotransmitter-driven conductance change but also the voltage-dependent driving force of the inhibitory synapse. Along with time-varying conductance, the driving force can change over time as the membrane potential becomes depolarised by excitatory current and the reversal potential of the $G_{A B A_{A} R}$ (EGABA) increases as $\mathrm{Cl}^{-}$flows into the cell and is not sufficiently compensated for by $\mathrm{Cl}^{-}$extrusion mechanisms [40].

The impact of accounting for dynamic $\mathrm{Cl}^{-}$on the $\mathrm{IL}$ was investigated over time for a single branch (Figure $5 \mathrm{Ai}$ ) as well as 4 branches (Figure 5Aii) with consistent inhibitory location, $\mathrm{i}=$ 0.2 , initial $\nabla E G A B A$ of $-5 \mathrm{mV}$, and constant excitatory input as previously mentioned. Along 
bioRxiv preprint doi: https://doi.org/10.1101/2021.12.07.471404; this version posted December $8,2021$. The copyright holder for this preprint (which was not certified by peer review) is the author/funder, who has granted bioRxiv a license to display the preprint in perpetuity. It is made available under aCC-BY 4.0 International license.

Results

with heatmaps of absolute IL over time for both static $\mathrm{Cl}^{-}$(where intracellular $\mathrm{Cl}^{-}$levels were held static, $\mathrm{IL}_{\text {stat }}$ ) and dynamic $\mathrm{Cl}^{-}$(where intracellular $\mathrm{Cl}^{-}$levels were allowed to fluctuate, $\mathrm{IL}_{\text {dyn }}$ ), the difference in $\mathrm{IL}\left(\Delta \mathrm{IL}=\mathrm{IL}_{\text {stat }}-\mathrm{IL}_{\text {dyn }}\right)$, the relative $\mathrm{IL}$ at a time point, and EGABA were also shown in Figure 5A. The heatmaps up until now have used the relative IL, indicated by "min" and "max" instead of absolute values. The development of IL over time was recorded at the inhibitory synapse location ( $\mathrm{IL}_{\mathrm{d}=\mathrm{i}}$ ), $\mathrm{i}=0.2 \mathrm{X}$, for both static $\mathrm{Cl}^{-}$(Figure $5 \mathrm{~B}$, dash-dot lines) and dynamic $\mathrm{Cl}^{-}$(Figure 5B, solid lines), as well as the $\Delta \mathrm{IL}$ (shaded area, same heatmaps as in Figure 5A).

It was immediately apparent that with ongoing synaptic input, the IL of dendrites with dynamic $\mathrm{Cl}^{-}$decreased compared to the same dendrite with static $\mathrm{Cl}^{-}$(Figure $5 \mathrm{~A}$ and B). Additionally, a dendrite with dynamic $\mathrm{Cl}^{-}$took longer to reach its steady-state IL value, which would require $\mathrm{Cl}^{-}$influx at the synapse to be matched by $\left[\mathrm{Cl}^{-}\right]_{i}$ extrusion mechanisms. In most cases, this had not occurred by the end of a $1 \mathrm{~s}$ simulation (Figure 5B). Underlying the difference in IL between a dendrite with static $\mathrm{Cl}^{-}$and dynamic $\mathrm{Cl}^{-}$was an increase in EGABA focused at i even though its effect, $\triangle \mathrm{IL}$, was more broadly apparent across the dendrite (Figure $5 \mathrm{~A}$ ). Because $\mathrm{Cl}^{-}$ diffuses slowly along the dendrite, compared to voltage propagation, EGABA changes remained relatively localised during 1 s of synaptic input (Figure $5 \mathrm{~A}$ ).

We next sought to determine how dynamic $\mathrm{Cl}^{-}$might affect the relative accumulation of IL at the shared branch junction as compared to the site of inhibitory synaptic input (Accldx). Although IL is dependent on EGABA, Figure 2D suggests that for negative $\nabla E G A B A$, the relative difference between $\mathrm{IL}$ at the inhibitory synapse and $\mathrm{IL}$ at the junction, i.e. the Accldx, remains relatively constant. To confirm constant Accldx during changing $\nabla E G A B A$, due to the influence of dynamic $\mathrm{Cl}^{-}$, the $\Delta \mathrm{I}$ at the synapse, $\Delta \mathrm{IL}_{\text {synapse }}$ (Figure $5 \mathrm{C}$, solid line, left $\mathrm{y}$-axis), and $\Delta \mathrm{IL}$ at the junction, $\Delta \mathrm{IL}$ junction (Figure $5 \mathrm{C}$, dotted line, right y-axis), were plotted for multiple branches. In each case, although the absolute values were different, the trajectories matched. Considering both changes are in proportion, the Accldx remains constant over time for each branch structure, after an initial period of capacitance charge (Figure $5 \mathrm{E}$ ).

Similarly, the change in EGABA was approximately the same for each dendritic structure (Figure 5D). Along with the EGABA heatmaps in Figure 5A, these results indicate that changes in EGABA were relatively localised when $\mathrm{i}=0.2 \mathrm{X}$. Thus, the Accldx seemed to be independent of EGABA during simulations with dynamic $\mathrm{Cl}^{-}$. However, there was a dependence on the number of branches as previously established (Figure 2D).

Together, these results show that local changes of EGABA at the synapse caused broad depression in $\mathrm{IL}_{\text {dyn }}$ across the dendrites over time. Although $\mathrm{IL}_{\text {dyn }}$ changed differently along a dendrite, the Accldx remained constant. Thus, the accumulation of GABAergic synapses' inhibitory efficacy still occurs even as their absolute efficacy diminishes.

Dynamic chloride differentially changes the efficacy of dendritic inhibition and dictates optimal synapse distributions.

One of the goals of dendritic inhibition is to maximise the suppression of nearby depolarizing excitatory current. For the case of static $\mathrm{Cl}^{-}$, IL would necessarily be greatest when all the inhibitory synapses are located at a shared branch junction $\left(\mathrm{IL}_{\mathrm{d}=\mathrm{i}=0}\right.$, Figure 4$)$. However, given the results presented so far, it is not clear that this would remain the case for the more realistic case of dynamic $\mathrm{Cl}^{-}$. To determine how dynamic $\mathrm{Cl}^{-}$impacts $\mathrm{IL}$ and how this depends on 
bioRxiv preprint doi: https://doi.org/10.1101/2021.12.07.471404; this version posted December $8,2021$. The copyright holder for this preprint (which was not certified by peer review) is the author/funder, who has granted bioRxiv a license to display the preprint in perpetuity. It is made available under aCC-BY 4.0 International license.

Results

inhibitory location, the IL for co-located excitatory and inhibitory input, $\mathrm{IL}_{\mathrm{d}=\mathrm{i}}$, was investigated in single and four branched dendrites with varying inhibitory locations, i. Simulations were run for $500 \mathrm{~ms}$ with initial $\nabla E G A B A$ at $-5 \mathrm{mV}$ and allowed to vary when $\mathrm{Cl}^{-}$was dynamic (see Methods).

For a single dendrite, the $\mathrm{IL}_{\mathrm{d}=\mathrm{i}}$ for static $\mathrm{Cl}^{-}\left(\mathrm{IL}_{\text {stat; }}\right.$; Figure 6A, first heatmap row and Figure 6B, inverse triangles) had little deviation and was symmetrical around $X=0.5$. The $\mathrm{IL}_{d=i}$ for dynamic $\mathrm{Cl}^{-}$( $\mathrm{IL}_{\text {dyn }}$; Figure 6A second heatmap row and Figure 6B, triangles), was lower compared to $\mathrm{IL}_{\text {stat }}$ for every inhibitory synapse location, and much lower at the ends of the branch ( $\mathrm{i} \approx 0$ Figure $6 \mathrm{~B}$, left inset, and $\mathrm{i} \approx 1$ Figure $6 \mathrm{~B}$, right inset). This drop-off in $\mathrm{IL}_{\text {dyn }}$ at the ends demonstrates the integral role of $\mathrm{Cl}^{-}$diffusion in reducing $\mathrm{Cl}^{-}$loading: $\mathrm{Cl}^{-}$could only diffuse in a single direction at the branch ends.

For a dendrite with four branches, as demonstrated previously, IL $\mathrm{L}_{\text {stat }}$ was highest at the junction $(\mathrm{i}=\mathrm{d}=0 \mathrm{X}$ ) and decreased with distance from the junction (Figure 6C, first heatmap row and Figure $6 \mathrm{D}$, inverse triangles). However, for the case of dynamic $\mathrm{Cl}^{-}$, the $\mathrm{IL}_{\text {dyn }}$ (IL with dynamic $\mathrm{Cl}^{-}$) was highest near - but not at - the junction. This demonstrated how $\mathrm{Cl}^{-}$accumulation weakened inhibition when the synapses were collocated at the junction. That is, $\mathrm{Cl}^{-}$flux through the collocated inhibitory synapses resulted in larger local increases in $\mathrm{Cl}^{-}$ concentration and positive shifts in $\mathrm{EEGABA}$. It was only when the inhibitory synapses were located a sufficient distance away from the junction and each other (Figure 6D, left inset), i.e. $\mathrm{i} \sim 0.07 \mathrm{X}$ from the junction, that this was ameliorated and $\mathrm{I} \mathrm{L}_{\mathrm{dyn}}$ reached its maximum value (Figure 6C, second heatmap row and Figure 6C, triangles). The effects of elevated EGABA through $\mathrm{Cl}^{-}$loading when all four synapses were located at, or very close to, the junction were also evident when we plotted the IL difference $\left(\Delta \mathrm{IL}\right.$, the difference between IL with static $\mathrm{Cl}^{-}$ and IL with dynamic $\mathrm{Cl}^{-}$) as well as heatmaps of EGABA (Figure $6 \mathrm{C}, \mathrm{D}$ ). Thus, although $\mathrm{IL}_{\text {dyn }}$ at or close to a junction may be highest initially ( $-5 \mathrm{mV} \nabla E G A B A)$, with continued inhibitory synaptic drive, this $I L_{d y n}$ would become the weakest due to each inhibitory synapse contributing to a highly pooled $\mathrm{Cl}^{-}$load ( $\geq 0 \mathrm{mV}$ VEGABA). Lower left and right insets in Figure $6 \mathrm{D}$ further highlight the degraded $\mathrm{IL}_{\text {dyn }}$ for dynamic $\mathrm{Cl}^{-}$which occurred at junctions and sealed ends ( $\mathrm{i}=0$ and $\mathrm{i}=1$, respectively).

Our results thus far have indicated a trade-off between maximising IL by having inhibitory synapses at junctions with an initial very negative EGABA, and the cumulative degrading effect that pooled inhibitory input has on the IL due to $\mathrm{Cl}^{-}$loading. The "sweet spot" for an inhibitory location, therefore, lies a small distance away from a junction where $\mathrm{Cl}^{-}$can diffuse away in multiple directions, but inhibitory effects can still accumulate at the shared branch point. This multi-directional diffusion works to help prevent pooling of multiple $\mathrm{Cl}^{-}$currents, which could overwhelm local $\mathrm{Cl}^{-}$extrusion. This "sweet spot" distance from the junction depends on the number of branches, number of inhibitory synapses, strength of inhibition (strongly related to the rate of $\mathrm{Cl}^{-}$influx), $\mathrm{Cl}^{-}$extrusion rate, $\mathrm{Cl}^{-}$diffusion rate, and the size of the neuronal compartments.

Finally, in the context of realistic $\mathrm{Cl}^{-}$dynamics, we specifically explored how different synaptic distributions at different locations over the entire dendrite, might drive the greatest dampening of dendritic excitability, i.e., drive the maximum IL. The only constraint we applied was that although synapses could be placed anywhere, the total number of inhibitory synapses equalled the total number of branches for any given simulation. Put another way, given the same number of synapses as branches, where should these be placed to drive the maximum 
bioRxiv preprint doi: https://doi.org/10.1101/2021.12.07.471404; this version posted December $8,2021$. The copyright holder for this preprint (which was not certified by peer review) is the author/funder, who has granted bioRxiv a license to display the preprint in perpetuity. It is made available under aCC-BY 4.0 International license.

Discussion

possible IL in a dendritic tree? We performed this with the three different synaptic distributions: encircling a junction, "Tree", all at the same place, "Focal", or all distributed on a single branch, "Branch".

Figure 7 summarises our findings where the "sweet spot" distance for maximising IL while mitigating $\mathrm{Cl}^{-}$loading depended on the number of branches and the distribution of the inhibitory synapses (Figure 7A). Because previous results indicated the greatest site of IL was either at the inhibitory synapse itself or at the junction, we specifically simulated recording from both locations to see their different responses. As before, dendrites with the "Tree" distribution had their maximum IL at the junction ( $\left.I L_{0}\right)$ when the inhibitory synapses were placed close to, but not at, the junction $(\approx 0.08 \mathrm{X})$. With an increased number of branches, the site of maximum ILo became slightly farther from the junction. Similarly, the maximum IL at the inhibitory synapses $\left(I \mathrm{~L}_{\mathrm{d}=\mathrm{i}}\right)$ for the "Tree" distribution was reached when the inhibitory synapses were located near $0.08 \times$.

If all the synapses were on top of each other, as in the "Focal" distribution, then the $\mathrm{Cl}^{-}$for all the inhibitory synapses would be concentrated in one area. This focal point worsens $\mathrm{Cl}^{-}$ loading by multiple inhibitory synaptic activation in a limited volume segment with a restricted space for $\mathrm{Cl}^{-}$to be cleared via diffusion and surface-bound $\mathrm{Cl}^{-}$extrusion mechanisms. This typically resulted in $\nabla E G A B A$ becoming positive, especially for many synapses, and negating the inhibitory effect of GABAergic transmission. Spreading the inhibitory synapses evenly along a branch, "Branch" distribution, resulted in broad, but relatively low maximum IL (Figure 7A, rightmost panel).

In summary, encircling a junction ("Tree") was most effective at dampening excitation, with the maximum IL occurring at the junction itself when inhibitory synapses were placed at 0.07 or $0.08 X$ away (Figure 7B). For a low $(\leq 2)$ number of branches, the maximum IL was at the inhibitory synapse itself $\left(\mathrm{IL}_{\mathrm{d}=\mathrm{i}}\right)$. However, for 4 and greater branches, the maximum IL was always at the junction (i.e. $\max I L=\max I L_{0}$ ). To highlight these placements, they were visualised with both IL and EGABA, relative to that neuron, and the optimal inhibitory synapse locations (downward triangles) and maximum IL ('V' markers) indicated (Figure 7C).

\section{Discussion}

Previous work has shown that activity-dependent $\mathrm{Cl}^{-}$accumulation can compromise the ability of dendritically targeted inhibition to control neuronal output in the form of action potential generation at the soma and axon initial segment [26]. However, it is now well appreciated that dendrites also host active conductances and that non-linear input integration occurs within the dendritic tree itself $[41,42]$. Therefore, how $\mathrm{Cl}^{-}$dynamics affect the ability of peripherally targeted inhibition to control dendritic excitatory input is an important issue that remains unexplored. Here we use a metric (the inhibitory level, IL), to quantify the extent to which multiple inhibitory synapses (with variable EGABAs) can control excitatory depolarization within dendritic trees. This allowed us to determine the optimal spatial distribution of inhibitory synapses to maximise local dendritic inhibition.

We find that GABAergic synapses with more negative EGABA are considerably better at suppressing local dendritic excitation (increased IL). Extending this, multiple GABAergic synapses can cause greater inhibitory suppression at a shared branch junction than at any of the inhibitory synapses themselves. This agrees with a previous study that demonstrated this 
bioRxiv preprint doi: https://doi.org/10.1101/2021.12.07.471404; this version posted December $8,2021$. The copyright holder for this preprint (which was not certified by peer review) is the author/funder, who has granted bioRxiv a license to display the preprint in perpetuity. It is made available under aCC-BY 4.0 International license.

Discussion

effect for shunting inhibition [21]. Interestingly, while absolute IL is increased with more negative EGABAs, the relative ratio of the $\mathrm{IL}$ at the junction compared to at the synapses themselves (i.e., the accumulation of inhibitory effectiveness), is constant regardless of EGABA. This suggests that although EGABA sets the strength of inhibition itself, the number of branches and their occupancy by GABAergic synapses sets the relative accumulation of inhibition at a shared branch point.

If EGABA is considered a static variable, the most powerful absolute local inhibition will always be generated if all available inhibitory synapses are placed at the same location; for example, at a branch junction or at the same location of a dendritic branch. In reality, however, EGABA is susceptible to incoming $\mathrm{Cl}^{-}$currents through $\mathrm{GABA}_{A} \mathrm{Rs}$. This is because synaptic $\mathrm{Cl}^{-}$ currents, if large enough, can overwhelm local extrusion $\mathrm{Cl}^{-}$mechanisms and reduce the transmembrane $\mathrm{Cl}^{-}$gradient [29]. Our results clearly illustrate the detrimental effects of clustering all available inhibitory synapses at the same location. The intuitive reasoning is that local $\mathrm{Cl}^{-}$diffusion and transmembrane extrusion may be overwhelmed by the cumulative effect of $\mathrm{Cl}^{-}$currents via multiple GABAergic synapses at the same location. Indeed, this could be part of the reason inhibitory synapses cluster less on branches than their excitatory counterparts $[39,43,44]$.

When accounting for dynamic $\mathrm{Cl}^{-}$, temporal factors like duration and frequency of input become an important consideration for understanding the effectiveness of dendritic inhibition $[26,27]$. For example, a low-frequency burst or short duration of inhibitory activity will result in negligible $\mathrm{Cl}^{-}$concentration changes and, therefore, the IL can be calculated instantaneously using analytical or semi-analytical methods (Eqs. 3 or 2, respectively). However, highfrequency bursts or sustained inputs can have dramatic changes on $\left[\mathrm{Cl}^{-}\right]_{i}$ that, as we have demonstrated here, strongly affect IL and should be considered under a different framework that includes the time component of $\left[\mathrm{Cl}^{-}\right]_{i}$ loading (Eq. 1). Similarly, models of branched dendritic trees have previously been conceptually and mathematically reduced to a single large cylinder with the same inputs $[19,45]$. It is important to note that this approach of equivalent cylinders does not hold for the case of dynamic $\mathrm{Cl}^{-}$, as the precise morphological structure (volume, surface area, compartmental ion differences, etc.) dictate the kinetics of $\mathrm{Cl}^{-}$ dynamics and consequent effects on GABAergic inhibition.

Given the reality of $\mathrm{Cl}^{-}$dynamics in dendrites, our simulations predict that the optimal distribution of available GABAergic synapses to maximise local inhibition in a branched dendritic tree is to place synapses surrounding, but not at, a branch junction. This allows centripetal accumulation of inhibitory effectiveness while minimising the detrimental effects of $\mathrm{Cl}^{-}$loading that occurs when GABAergic synapses are all placed at the same location. Indeed, experimental evidence suggests that dendritic inhibition (typically from somatostatinexpressing - $\mathrm{SOM}^{+}$- interneurons) is widely distributed across pyramidal cell branches instead of clustering synapses on a single branch, or primary dendrite [12,39,46-48]. This strategy has several advantages. First, inhibitory synapses do not need to control excitation by directly targeting each excitatory synapse. Second, dendritic inhibition targeting a particular branch could control local integration there $[48,49]$, but activating widespread inhibitory synapses across multiple branches would be able to accumulate at a shared-branch junction, or primary dendrite, to gate the generation of dendritic action potentials and the associated burst firing of pyramidal neurons [50]. Third, this spatial arrangement would minimise the deleterious effects of $\mathrm{Cl}^{-}$accumulation with continued synaptic drive and the accompanying 
bioRxiv preprint doi: https://doi org/10.1101/2021 12 07.471404 - this version posted December 8,2021 . The copyright holder for this preprint (which was not certified by peer review) is the author/funder, who has granted bioRxiv a license to display the preprint in perpetuity. It is made available under aCC-BY 4.0 International license.

Discussion

potential for dendritic inhibition to fail, which would otherwise facilitate the onset of seizure activity [51].

Experimentally verifying the local effects of dendritic inhibition is incredibly challenging [11]. However, continually advancing methods allowing for more precise control of dendritic circuits, e.g. dendritic patching [52] and spatially controlled 2-photon uncaging of glutamate and GABA [53], could lead to the potential for direct experimental verification of our predictions for the optimal placement of GABAergic synapses to control local excitation. Taken together, our modelling work using simple dendritic structures provides a framework for understanding the optimal distribution of GABAergic synapses to maximise suppression of dendritic excitability. 
bioRxiv preprint doi: https://doi.org/10.1101/2021.12.07.471404; this version posted December 8, 2021. The copyright holder for this preprint (which was not certified by peer review) is the author/funder, who has granted bioRxiv a license to display the preprint in perpetuity. It is made available under aCC-BY 4.0 International license.

Figures

\section{FIGURES}

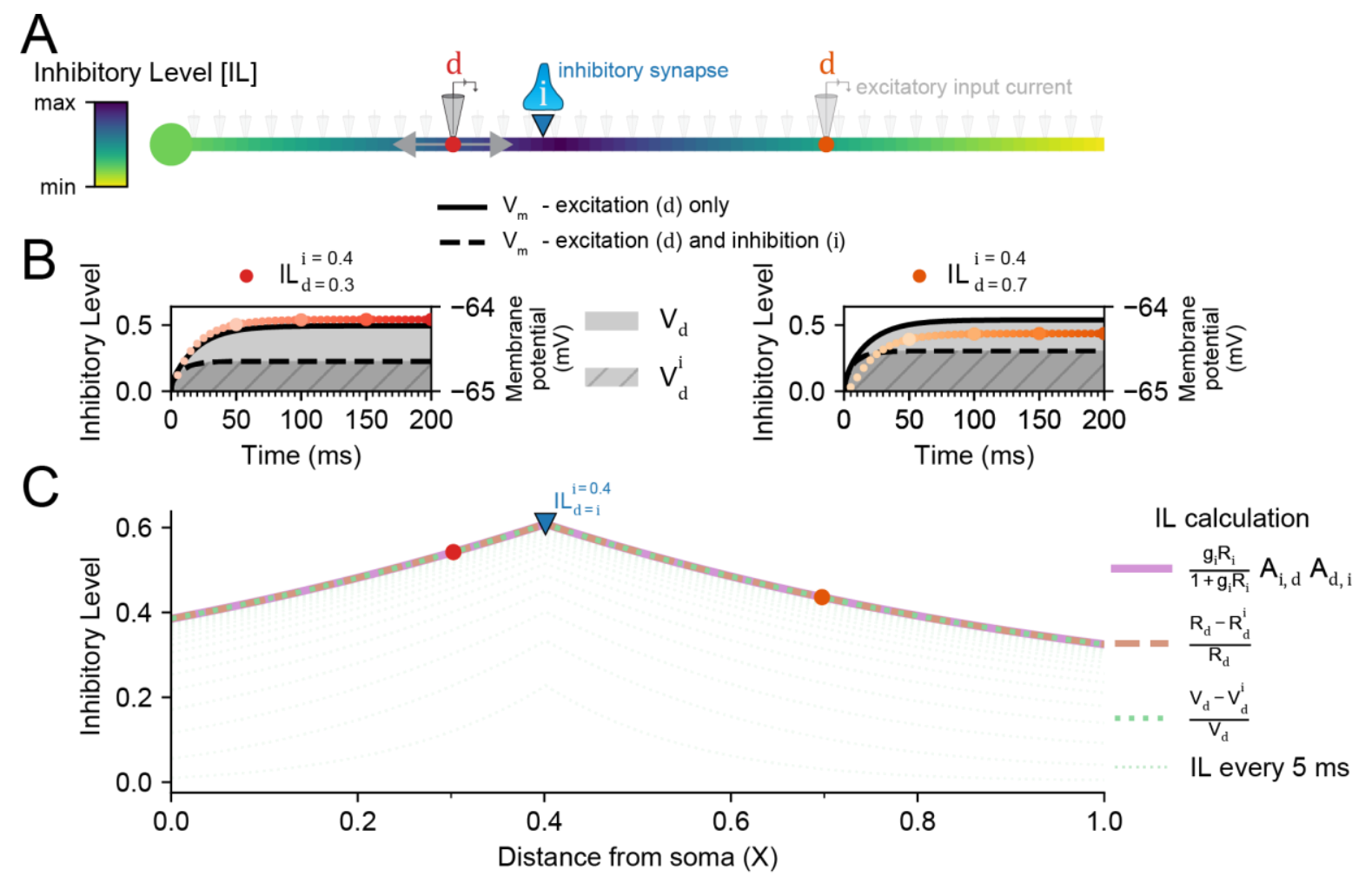

Figure 1 Inhibitory Level (IL) as a metric to assess the local efficacy of dendritic inhibition.

(A) The effect that an inhibitory synapse at location i (downward triangle) has on an excitatory input current at location $\mathrm{d}$ (circle) is termed the Inhibitory Level (IL). The IL at each location d, for stationary i at $0.4 \mathrm{X}$, is shown for the full length of the dendrite. (B) The IL is calculated by recording the membrane potential with only excitation at $\mathrm{d}$ (solid black line) or excitation at $\mathrm{d}$ and inhibition at $\mathrm{i}$ (dashed black line). The relative difference in the deflection of the membrane potential from rest, between $V_{d}$ (without inhibition; shaded area) and $V^{i_{d}}$ (with inhibition; striped shaded area), is the IL (circles). IL with an integration time window $\Delta \mathrm{t}$ of $5 \mathrm{~ms}$ for $\mathrm{d}=0.3 \mathrm{X}$ (left, shades of red circles) or $\mathrm{d}=0.7 \mathrm{X}$ (right, shades of orange circles) shows that the steady-state IL is reached within $150 \mathrm{~ms}$. Small circles are IL every $5 \mathrm{~ms}$. Bigger circles are every $50 \mathrm{~ms}$. (C) For shunting inhibition, and given sufficient duration, the numerical calculation of IL (dotted green line) matches the semi-analytical (dashed brown line) and analytical (solid purple line) solutions. The inhibitory synapse was modelled as a fluctuating GABAA conductance, $\langle\mathrm{g}\rangle=0.001$ $\mu \mathrm{S}, \sigma^{2}=0.1 \times\langle\mathrm{g}\rangle$, and the excitatory input as a constant current, $0.001 \mathrm{nA} . \mathrm{C}_{\mathrm{m}}=1 \mu \mathrm{F} / \mathrm{cm}^{2}, \mathrm{~L}=707 \mu \mathrm{m}, \mathrm{r}=1.0$ $\mu \mathrm{m}, \mathrm{R}_{\mathrm{m}}=10 \mathrm{M} \Omega \cdot \mathrm{cm}^{2}$, and $\mathrm{R}_{\mathrm{a}}=0.1 \mathrm{M} \Omega \cdot \mathrm{cm}$. 
bioRxiv preprint doi: https://doi.org/10.1101/2021.12.07.471404; this version posted December 8, 2021. The copyright holder for this preprint (which was not certified by peer review) is the author/funder, who has granted bioRxiv a license to display the preprint in perpetuity. It is made available under aCC-BY 4.0 International license.

Figures
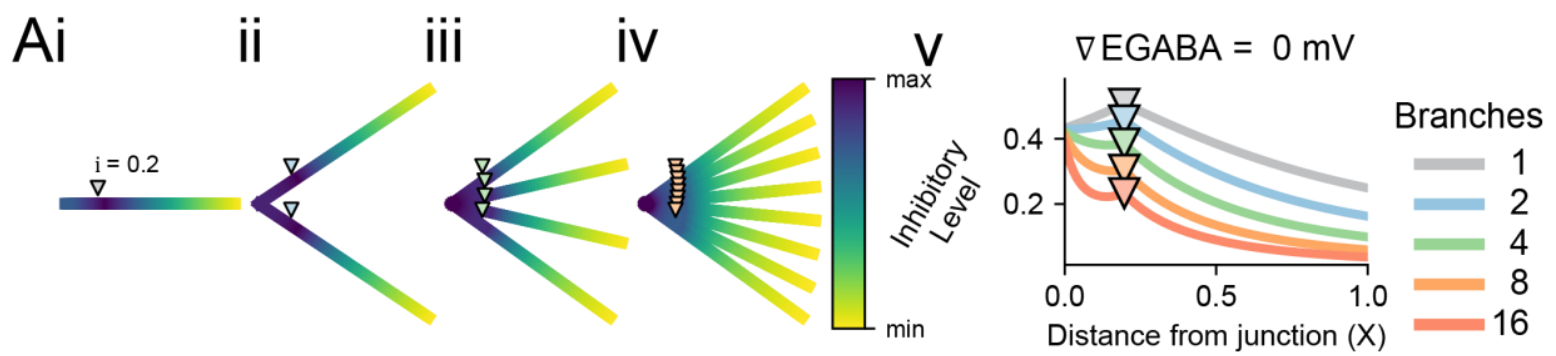

$\mathrm{Bi}$
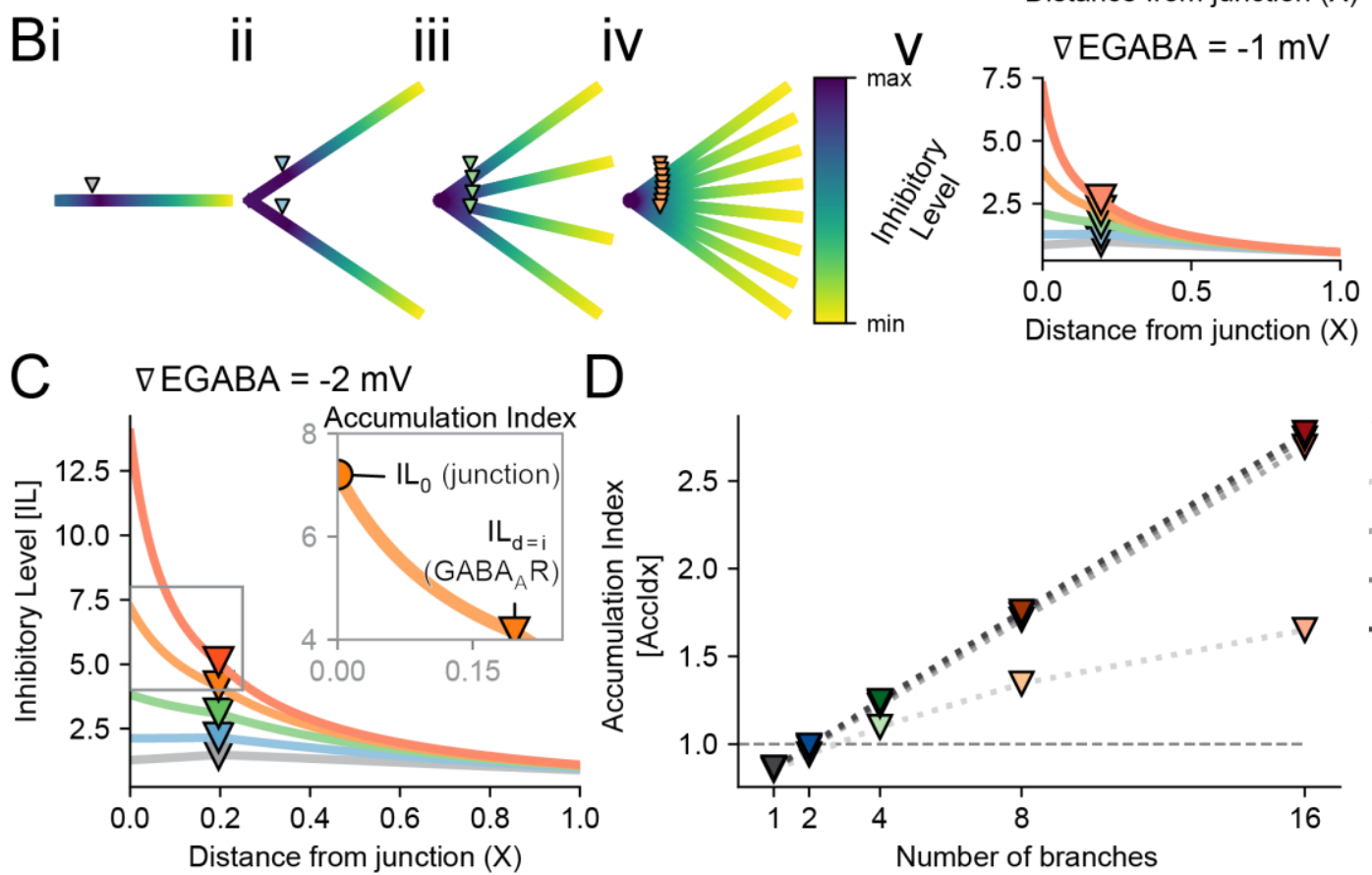

D

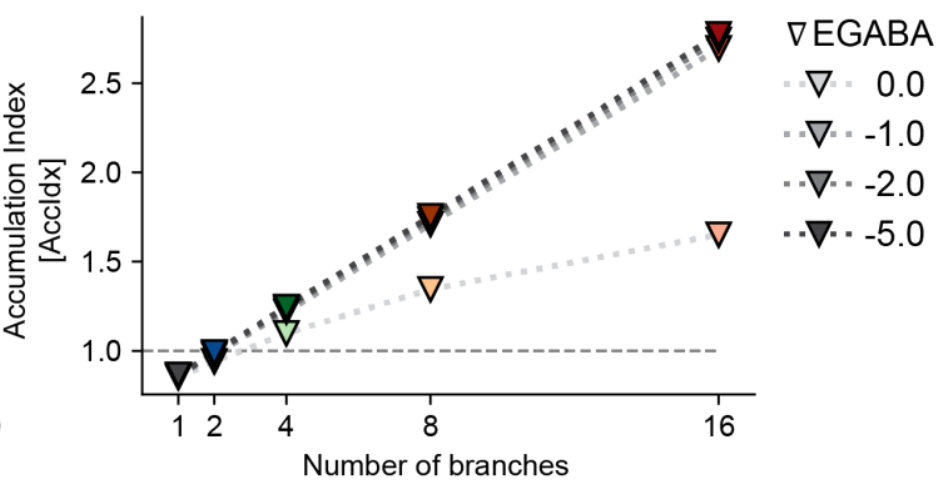

Figure 2 Dendritic inhibition has a cumulative effect at a dendritic junction.

(A) The point of maximum Inhibitory Level (IL) for shunting inhibitory synapses at $0.2 \mathrm{X}$ (downward triangle) shifts to the junction as the number of dendritic branches increases, as shown by the heatmaps in 'Ai-iv' and summarised in 'Av'. The "max" and "min" in the IL heatmaps are the maximum and minimum IL values for each morphology (in contrast to a shared heatmap across all morphologies). (B) When EGABA is set hyperpolarised to the resting membrane potential $(\nabla E G A B A<0)$, the inhibitory synapse no longer only shunts (pure conductance-driven effect) but instead also has an additional inhibitory postsynaptic potential (IPSP) contribution. 'Bi-iv' shows the IL heatmaps for 1 (Bi), 2 (Bii), 4 (Biii), and 8 (Biv) equal dendritic branches for a hyperpolarising inhibitory synapse at $-1 \mathrm{mV}$ below resting $\mathrm{V}_{\mathrm{m}}$. 'Bv' shows the corresponding IL values, along with a morphology that has 16 branches. (C) IL for an inhibitory synapse with an $\nabla E G A B A$ of $-2 \mathrm{mV}$. (C, inset) IL for 8 branches between the junction at 0.0 $X$ and the inhibitory synapse at $\mathrm{i}(\mathrm{X}=0.2$ in this figure). The ratio between the IL at the junction (ILo) and the IL at $\mathrm{i}$ $\left(I L_{d=i}\right)$ is the Accumulation Index (Accldx) and reflects the cumulative effect of inhibitory synapses on multiple dendrites at a junction. (D) Accumulation Index as a function of the number of branches and the relative reversal potential (DEGABA) of the inhibitory synapse (shade of downward triangles). 
bioRxiv preprint doi: https://doi.org/10.1101/2021.12.07.471404; this version posted December 8, 2021. The copyright holder for this preprint (which was not certified by peer review) is the author/funder, who has granted bioRxiv a license to display the preprint in perpetuity. It is made available under aCC-BY 4.0 International license.

Figures
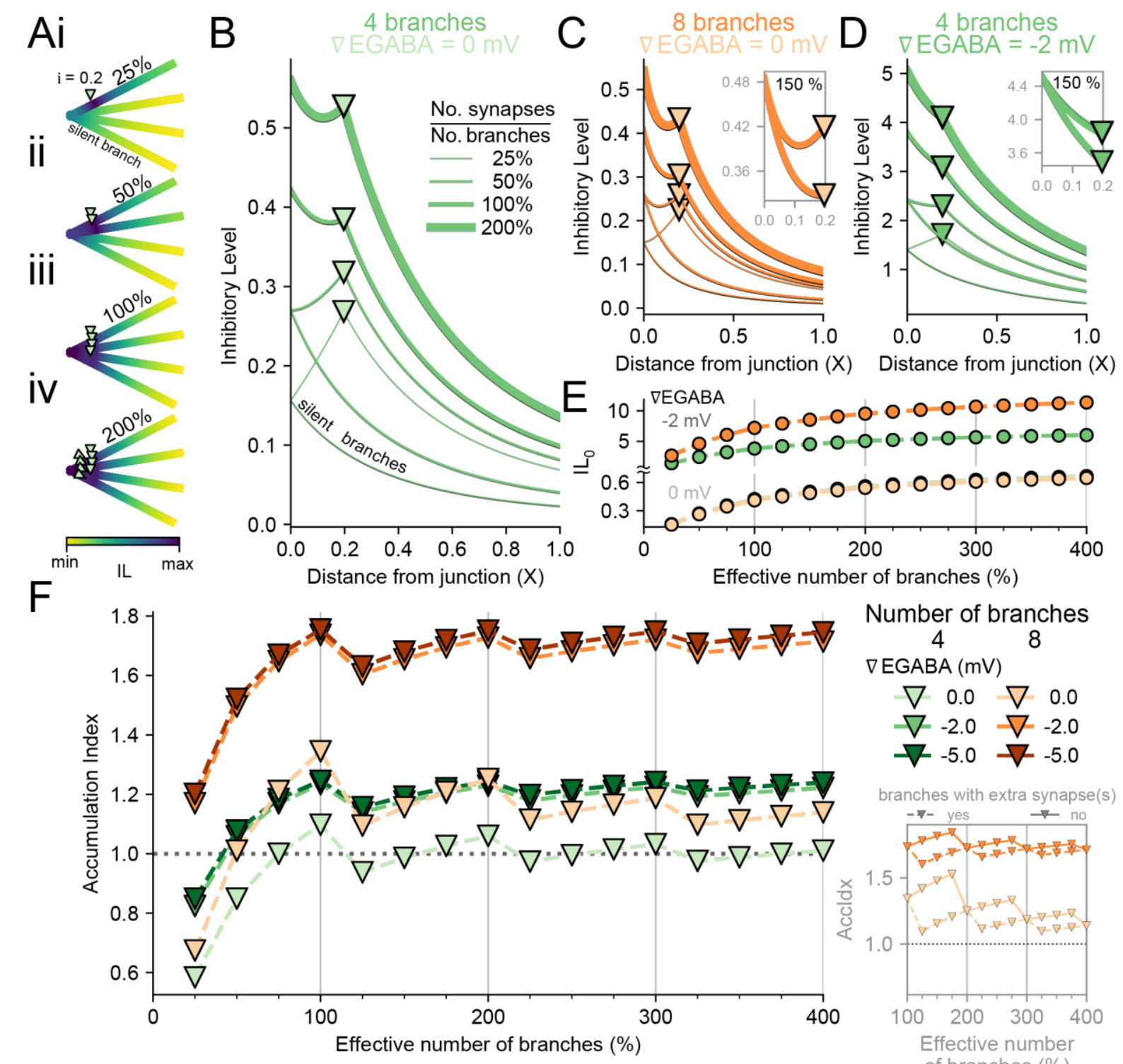

Distance from junction $(X)$

Number of branches

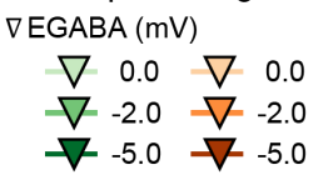

branches with extra synapse(s)

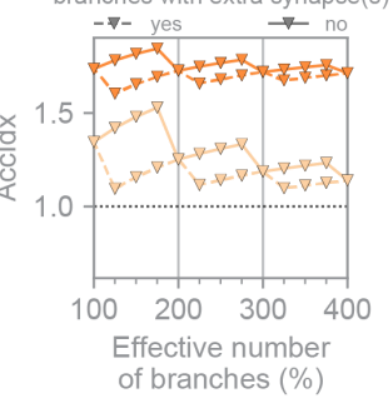

Figure 3 Increasing branch occupancy with inhibitory synapses enhances Inhibitory Level at the junction but saturates relative inhibitory accumulation.

(A) The percentage of dendritic branches which have inhibitory synapses, "effective number of branches", indicates the diminishing return in additional IL when adding more synapses. (Ai-iv) 4 branch structure with 1 (Ai, $25 \%$ ), 2 (Aii, $50 \%$ ), 4 (Aiii, $100 \%$ ), or 8 (Aiv, $200 \%$ ) inhibitory synapses (VEGABA $=0 \mathrm{mV}$ ). Note that inhibitory synapses are located at 0.2 , so for 8 synapses on 4 branches $(200 \%)$, there are 2 synapses per location. (B) IL as in 'A' for the effective number of synapses $\left(\frac{\text { number of synapses }}{\text { number of branches }}\right)$. Thinner lines indicate a lower effective number of synapses. Note that there is no " $\nabla$ " marker for branches without synapses, "silent branches". (C) As in 'B' but with 8 branches. Thus, $50 \%$ effective number of synapses for 8 branches is 4 of the branches with synapses and the other 4 without synapses. Inset, $150 \%$ (12/8) effective number of synapses has some branches with a single synapse and others with 2 synapses. The branches with extra synapses have stronger IL values while the branches without extra synapses have a moderately better IL than $100 \%$ effective number of synapses. (D) As in 'B' and 'C', but the synapses on the 4 branches each have $\nabla E G A B A=-2 \mathrm{mV}$. (E) The IL for shunting synapses (lower portion) and IL for hyperpolarising synapses (upper portion) at the junction for 4 and 8 branches with inhibitory synapses either at $\nabla E G A B A=0 \mathrm{mV}$ or $2 \mathrm{mV}$. Line and marker colours same as in ' $F$ '. (F) Accumulation Index for different dendritic structures when varying the effective number of synapses. Regardless of $\nabla E G A B A$ or number of branches, the Accldx is maximised at $100 \%$ effective number of synapses. As in Figure $2, \nabla E G A B A<0 \mathrm{mV}$ is shifted from $\nabla E G A B A=0 \mathrm{mV}$. Note that the number of synapses is equal for 8 branches with $50 \%$ effective number of branches and 4 branches with $100 \%$ effective number of branches (4 synapses). Inset, the Accldx for branches without extra synapses (short dashes) are greater than those with extra synapses (long dashes) because these branches utilise 
bioRxiv preprint doi: https://doi.org/10.1101/2021.12.07.471404; this version posted December 8, 2021. The copyright holder for this preprint (which was not certified by peer review) is the author/funder, who has granted bioRxiv a license to display the preprint in perpetuity. It is made available under aCC-BY 4.0 International license.

\section{Figures}

the boosted ILo facilitated by the branches with extra synapses. However, the difference in Accldx between branches with and without extra synapses decreases with the number of synapses. 
bioRxiv preprint doi: https://doi.org/10.1101/2021.12.07.471404; this version posted December 8, 2021. The copyright holder for this preprint (which was not certified by peer review) is the author/funder, who has granted bioRxiv a license to display the preprint in perpetuity. It is made available under aCC-BY 4.0 International license.

Figures

A

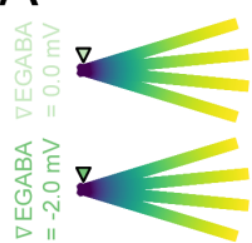

0.0

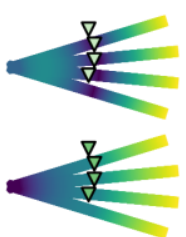

0.5

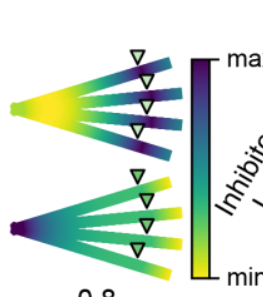

0.8
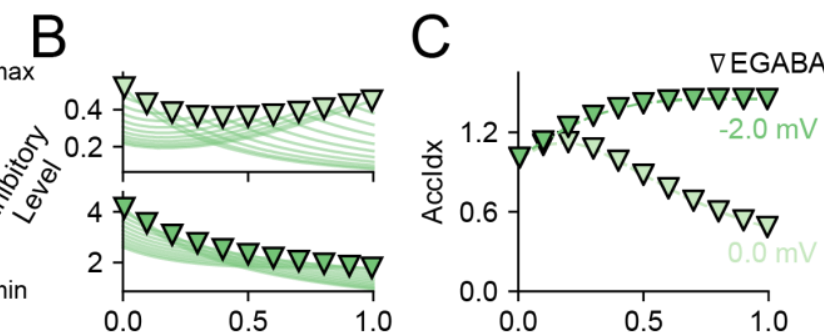

Inhibitory synapse location $(X)$ Inhibitory synapse location $(X)$

Di

nhibitory synapse location (X)

$\mathrm{ii}_{30}$

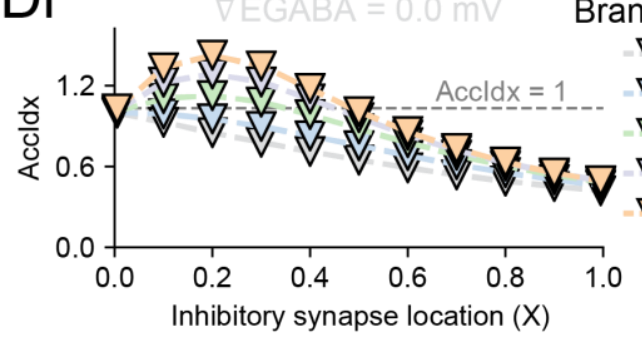

Branches

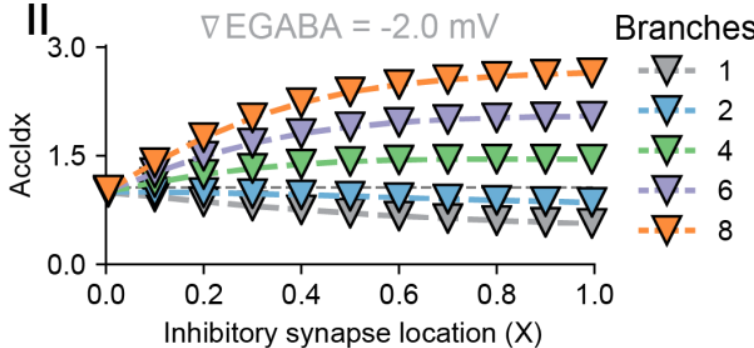

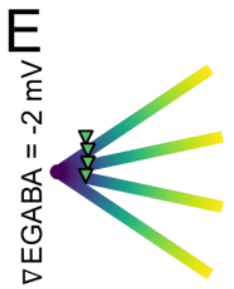

Tree

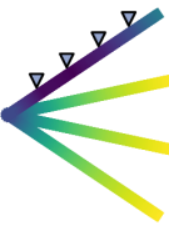

Branch

Distribution

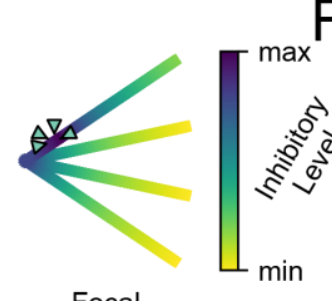

Focal

$\mathrm{F}$

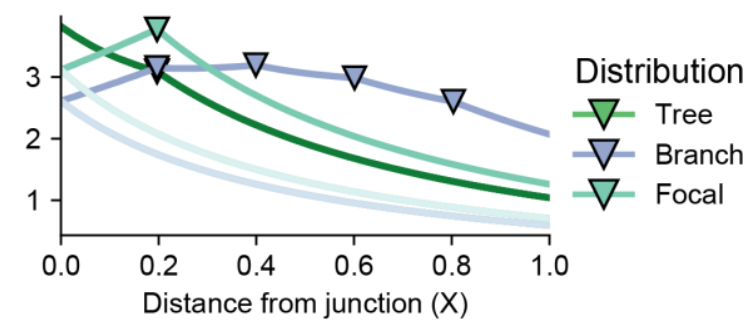

Figure 4 Location and distribution of inhibitory synapses differentially affect the Inhibitory Level.

(A) Heatmaps show the maximum IL ( $\nabla E G A B A=0 \mathrm{mV}$, light green markers, top row or $\nabla E G A B A=-2 \mathrm{mV}$, dark green markers, bottom row) for different inhibitory synapse locations, i, on a 4-branch dendritic structure. The inhibitory synapses are evenly placed from the junction $(0.0 \mathrm{X}$ in left column, $0.5 \mathrm{X}$ in centre column, $0.8 \mathrm{X}$ in right column). (B) The IL ( $\nabla E G A B A=0 \mathrm{mV}$, top and $\nabla E G A B A=-2 \mathrm{mV}$, bottom) for each inhibitory synapse location $\mathrm{i}$, in electrotonic units $X$, on a 4-branch dendrite. Each trace represents recordings at every excitatory input location $D$ along the dendrite for a given synapse location i. Inhibitory synapses at the junction, $\mathrm{i}=0 \mathrm{X}$, elicit the greatest IL. $\mathrm{I} \mathrm{L}_{\mathrm{d}=\mathrm{i}}$ for shunting synapses $(\nabla E G A B A=0 \mathrm{mV}$ ) is the lowest when inhibitory synapses are between the junction and the end of the dendrite $(0.4 \mathrm{X})$, yet $I L_{d=i}$ for hyperpolarising synapses ( $\left.\nabla E G A B A=-2 \mathrm{mV}\right)$ is the lowest at the end of the dendrite $(1.0 \mathrm{X})$. (C) The Accldx for 4 branches with hyperpolarising synapses ( $\mathrm{CEGABA}=-2 \mathrm{mV}$ ) continues to increase, albeit with saturation, with farther locations for inhibitory synapses. Shunting synapses $(\nabla E G A B A=0$ $\mathrm{mV}$ ), however, have their greatest Accldx when $\mathrm{i}=0.2 \mathrm{X}$. (D) The different trends in Accldx between shunting (Di) and hyperpolarising (Dii) inhibitory synapses, as in ' $\mathrm{C}$ ', holds for dendrites with more than 2 branches. For dendrites with 1 or 2 branches, the Accldx is greatest when $\mathrm{i}=0.0 \mathrm{X}$. For greater numbers of branches, the maximum Accldx depends on whether the synapse is shunting or hyperpolarising. (E) The maximum IL is dependent on the distribution of the synapses. A dendrite with 4 branches can have 4 synapses placed in different configurations: evenly spaced from the junction on each branch ("Tree"), evenly spaced along a single branch ("Branch"), or all placed at a single location on a single branch ("Focal"). Inhibitory synapses were hyperpolarising ( $\nabla E G A B A=-2$ $\mathrm{mV}$ ). (F) The IL values for the synapse distributions in ' $E$ '. Although the Tree configuration (green) produces an accumulative IL at the junction, the Focal distribution (turquoise) has the largest absolute IL (at $d=i=0.2 \mathrm{X}$ ), and the Branch distribution (lilac) facilitates a more even IL along its branch. However, both the Branch and Focal distributions are branch-selective and hence have to trade-off their gains for weaker ILs on their silent branches (lighter colours). 
bioRxiv preprint doi: https://doi.org/10.1101/2021.12.07.471404; this version posted December 8, 2021. The copyright holder for this preprint (which was not certified by peer review) is the author/funder, who has granted bioRxiv a license to display the preprint in perpetuity. It is made available under aCC-BY 4.0 International license.

Figures

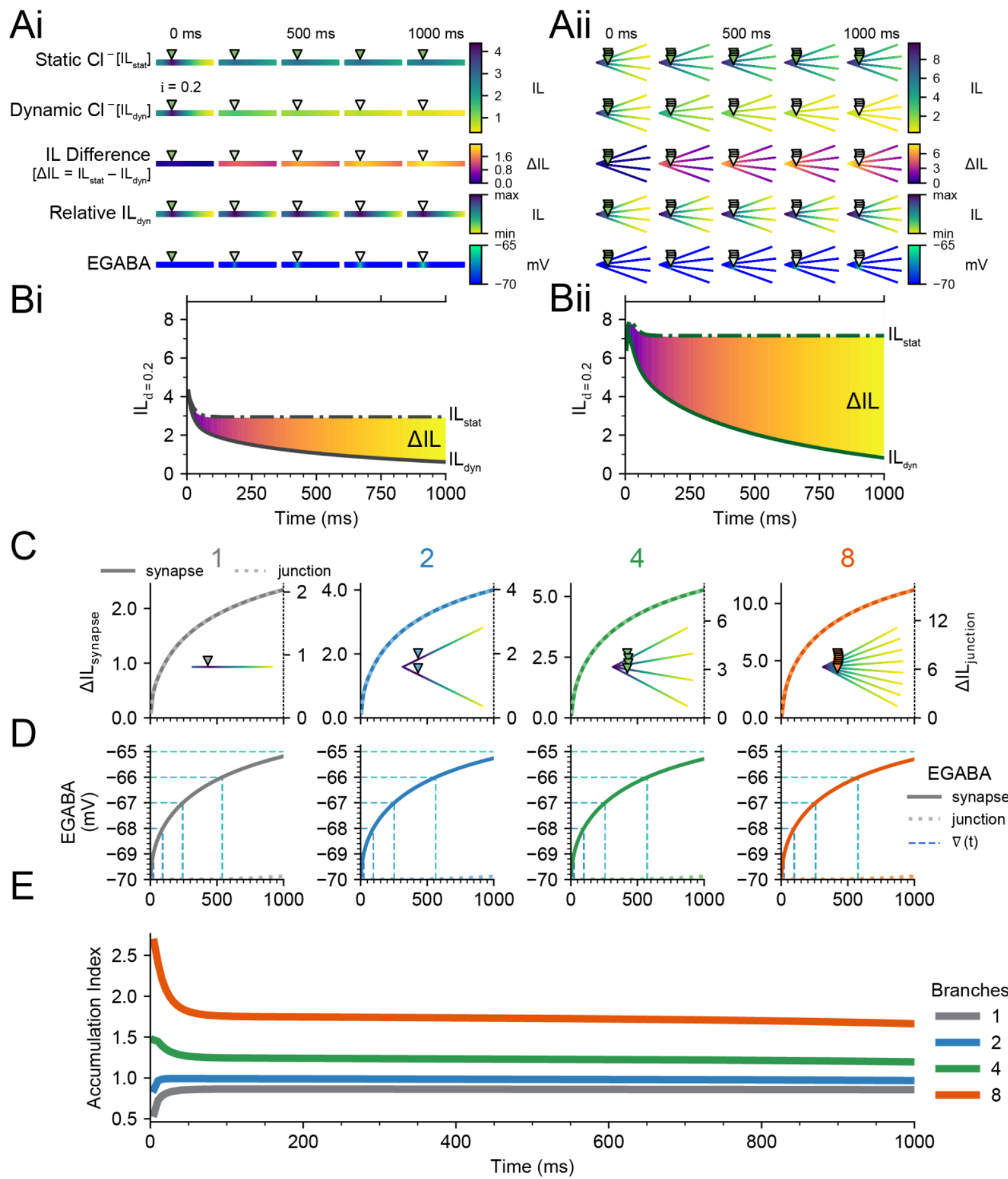

Figure 5 Chloride loading and shifts in EGABA progressively impact Inhibitory Level, but not Accumulation Index, over time.

(A) IL and related properties calculated at different points in time (5, 250, 500, 750, and $1000 \mathrm{~ms})$, with a backward time integration window, $\Delta \mathrm{t}$, of $5 \mathrm{~ms}$. At $5 \mathrm{~ms}$. A dendrite with a single branch, 'Ai', and a dendrite with four branches, 'Aii', is shown. IL with static $\mathrm{Cl}^{-}$(ILstat), and IL with dynamic $\mathrm{Cl}^{-}$(ILdyn), are identical. However, while $\mathrm{LL}_{\text {stat }}$ reaches its steady-state by the next time point, ILdyn continues to decrease. Note that the heatmap is shared across time as well as $\mathrm{IL}$ with static or dynamic $\mathrm{Cl}^{-}$. The difference between $\mathrm{IL}_{\text {stat }}$ and ILdyn, the IL Difference $(\Delta \mathrm{IL})$, is strongly focused at the site of the inhibitory synapse but spreads throughout the dendrite over time even while changes in EGABA remain local. The relative $I L_{d y n}$ ( $L_{\text {dyn }}$ scaled between that dendrite's minimum and maximum $I L_{d y n}$ ) indicates that although $\mathrm{LL}_{\mathrm{dyn}}$ changes over time, the changes are proportional. Initial $\nabla E G A B A$ was $-5 \mathrm{mV}$ (EGABA $=-70 \mathrm{mV}$, $V_{m}=-65 \mathrm{mV}$ ). (B) IL over a $1000 \mathrm{~ms}$ period for both a single-branch dendrite, 'Bi', and four-branch dendrite, 'Bii'. With prolonged input (1000 ms), ILstat decreases until the membrane capacitance is charged and ILdyn stabilises when an equilibrium is reached between $\mathrm{Cl}^{-}$influx (via GABAARs) and efflux (via KCC2). (C) The $\triangle \mathrm{IL}$ at the synapse 
bioRxiv preprint doi: https://doi.org/10.1101/2021.12.07.471404; this version posted December 8, 2021. The copyright holder for this preprint (which was not certified by peer review) is the author/funder, who has granted bioRxiv a license to display the preprint in perpetuity. It is made available under aCC-BY 4.0 International license.

\section{Figures}

(solid lines, left $y$-axes) and $\Delta \mathrm{I}$ at the junction (dotted lines, right y-axes) remain in proportion to each other over time, regardless of the number of branches in the dendrite. Note that the scales are different for each axis. These are location-specific traces of what is represented across the dendrite in "Relative IL" heatmaps. (D) EGABA at the synapse (solid lines) increases from $-70 \mathrm{mV}(-5 \mathrm{mV} \nabla E G A B A)$ to $\approx-65 \mathrm{mV}$ over $1000 \mathrm{~ms}$ as in ' $\mathrm{A}$ '. $E G A B A$ at the junction changes only marginally (dotted lines). Vertical dashed lines indicate the time at which EGABA reaches the corresponding horizontal integer values, $\nabla(t)$. (E) The proportional decrease in IL across the dendrite manifests as a consistent Accldx, except for during the initial few milliseconds when the membrane capacitance is charging. The Accldx depends on the number of branches, but not on EGABA or $\triangle \mathrm{IL}$. 
bioRxiv preprint doi: https:/doi.org/10.1101/2021.12 07.471404; this version posted December 8 2021. The copyright holder for this

preprint (which was not certified by peer review) is the author/funder, who has granted bioRxiv a license to display the preprint in perpetuity. It is made available under aCC-BY 4.0 International license.

Figures

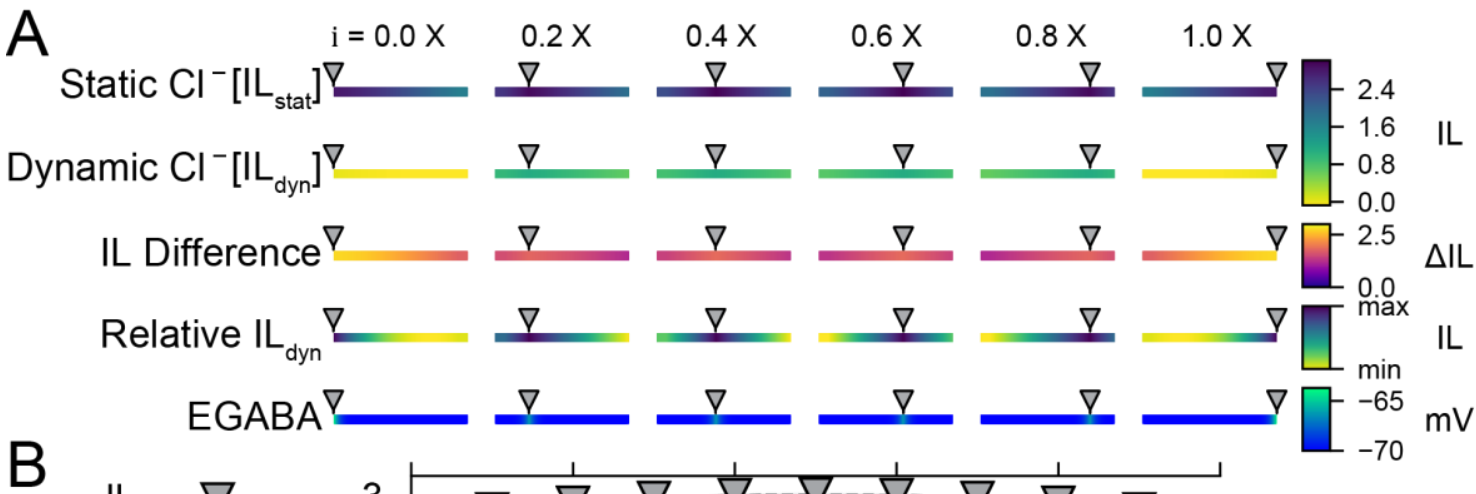

$\mathrm{B} \quad \mathrm{IL}_{\text {stat }}-\nabla^{-} \quad 3 \frac{1}{\nabla^{--} \nabla^{--} \nabla^{--} \nabla^{--} \nabla^{--} \nabla^{---} \nabla^{--} \nabla^{--} \nabla^{--} \nabla^{--} \nabla}$

$\mathrm{IL}_{\mathrm{dyn}}-\triangle$

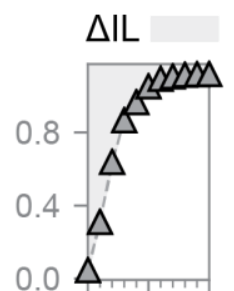

$0.0-0.1$

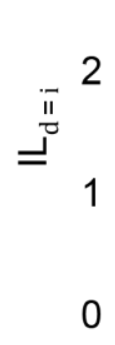

0.0 $\max I L_{\text {stat }}$ $\max I L_{\text {dyn }}$

C

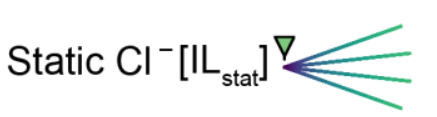

Dynamic $\mathrm{Cl}^{-}\left[\mathrm{IL}_{\mathrm{dyn}}\right] \nabla$

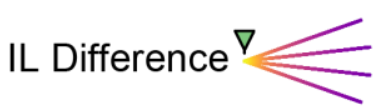

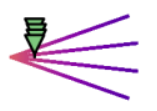

Relative $\mathrm{IL}_{\mathrm{dyn}} \mathrm{P}$
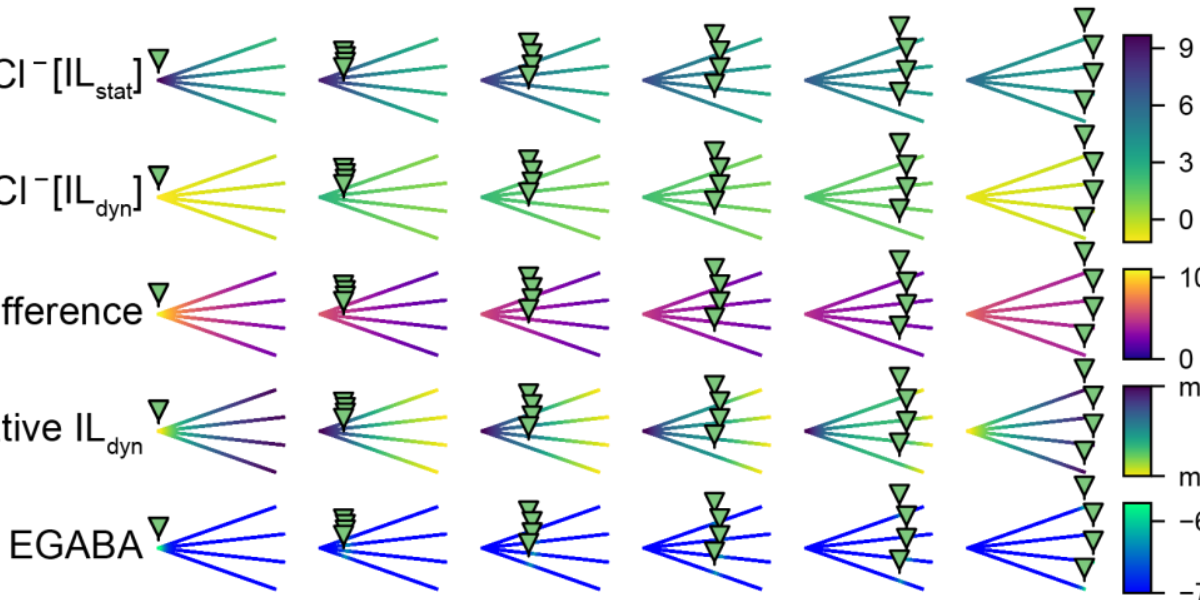

IL

$\mathrm{D}$

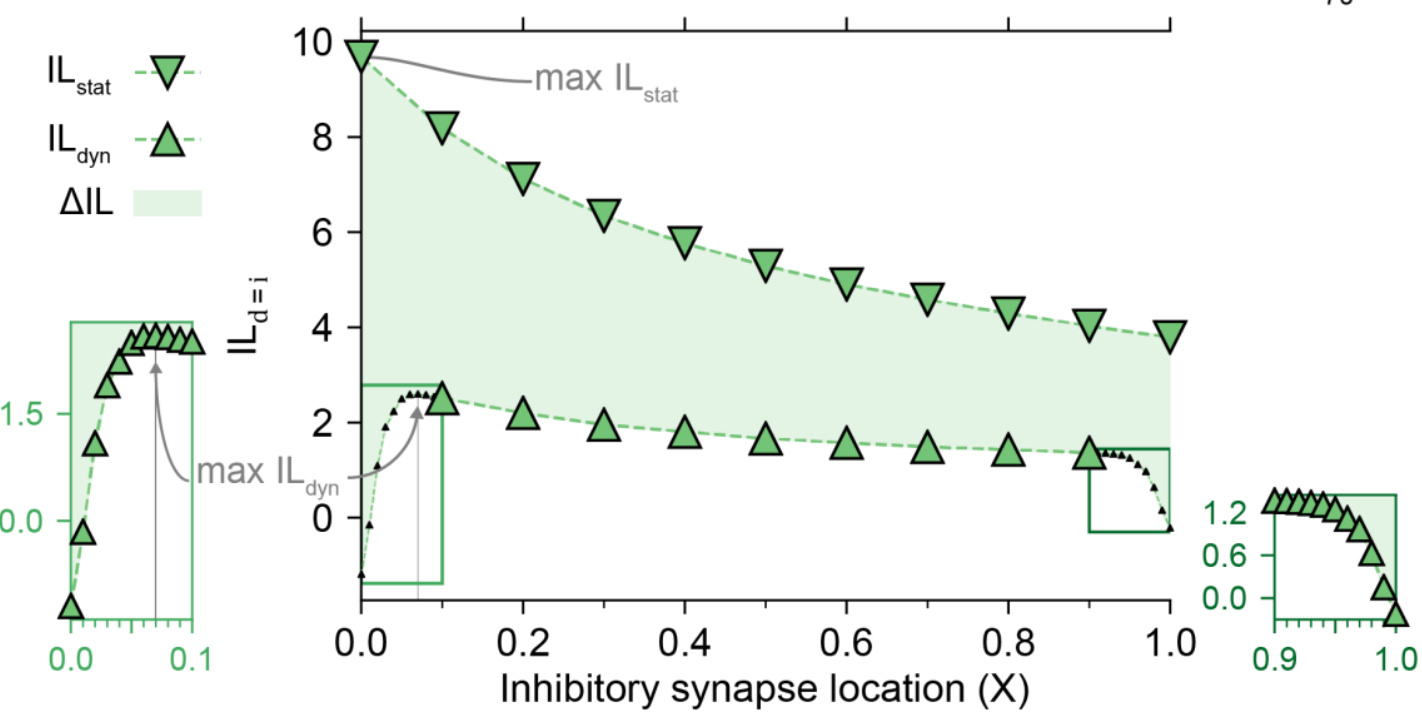


bioRxiv preprint doi: https://doi.org/10.1101/2021.12.07.471404; this version posted December 8, 2021. The copyright holder for this preprint (which was not certified by peer review) is the author/funder, who has granted bioRxiv a license to display the preprint in perpetuity. It is made available under aCC-BY 4.0 International license.

Figures

Figure 6 Dynamic chloride has a differential effect on Inhibitory Level depending on the location of inhibitory synaptic input.

(A) Heatmaps of a single-branched dendrite indicate how IL with static $\mathrm{Cl}^{-}(\mathrm{IL}$ stat $)$ and IL with dynamic $\mathrm{Cl}^{-}\left(\mathrm{IL}_{\text {dyn }}\right)$, the difference between these $(\Delta \mathrm{IL})$ are differentially affected by inhibitory synapse location $(0.0,0.2,0.4,0.6,0.8$, $1.0 \mathrm{X}$ ). In addition to heatmaps with values shared across synapse location, the relative IL heatmaps are independent of each other and indicate the IL throughout a dendrite scaled to that dendrite's minimum and maximum IL. Values for EGABA are also represented for each synapse location and indicate local changes in EGABA. All values are taken after $500 \mathrm{~ms}$. (B) IL with $\mathrm{d}$ at $\mathrm{i}, \mathrm{IL}=\mathrm{d}=\mathrm{i}$, for both static $\mathrm{Cl}^{-}$(inverse triangles) and IL with dynamic $\mathrm{Cl}^{-}$(triangles). The difference $(\Delta \mathrm{IL})$ is indicated by the shaded region. Left inset and right inset, when the inhibitory synapse is located near the ends of the branch, each ILdyn is dramatically lower than its ILstat counterpart due to $\mathrm{Cl}^{-}$loading. (C) Same as in 'A' but for a four-branch dendrite. Due to multiple branches sharing a junction, the difference between ILstat and ILdyn are largest at the junction $(0.0 \mathrm{X})$ and are no longer symmetrical around 0.5 $X$. (D) Same as in 'B' but for a four-branch dendrite. Although IL stat is strongest when inhibitory synapses are placed at the junction, $I L_{d y n}$ is weakest in this scenario. Instead, the maximum ILdyn occurs when inhibitory synapses are placed at $0.07 \mathrm{X}$. Left inset, concurrent activation of multiple inhibitory synapses close to each other causes $I \mathrm{~L}_{\text {dyn }}$ to rapidly decline when inhibitory synapses are close to the junction due to the pooled effects of $\mathrm{Cl}^{-}$loading. Right inset, the ends of the branches restrict the diffusion of $\mathrm{Cl}^{-}$and therefore also decrease ILdyn. 
bioRxiv preprint doi: https://doi.org/10.1101/2021.12.07.471404; this version posted December 8, 2021. The copyright holder for this preprint (which was not certified by peer review) is the author/funder, who has granted bioRxiv a license to display the preprint in perpetuity. It is made available under aCC-BY 4.0 International license.

Figures

A

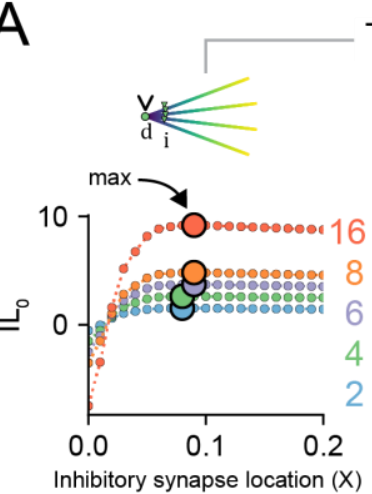

Tree
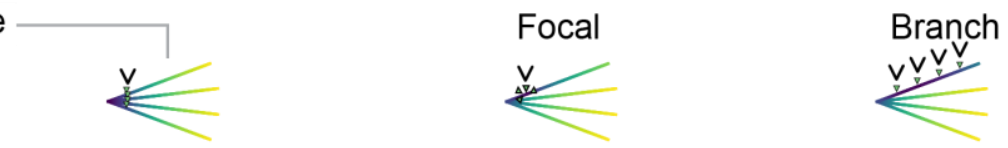

$B$
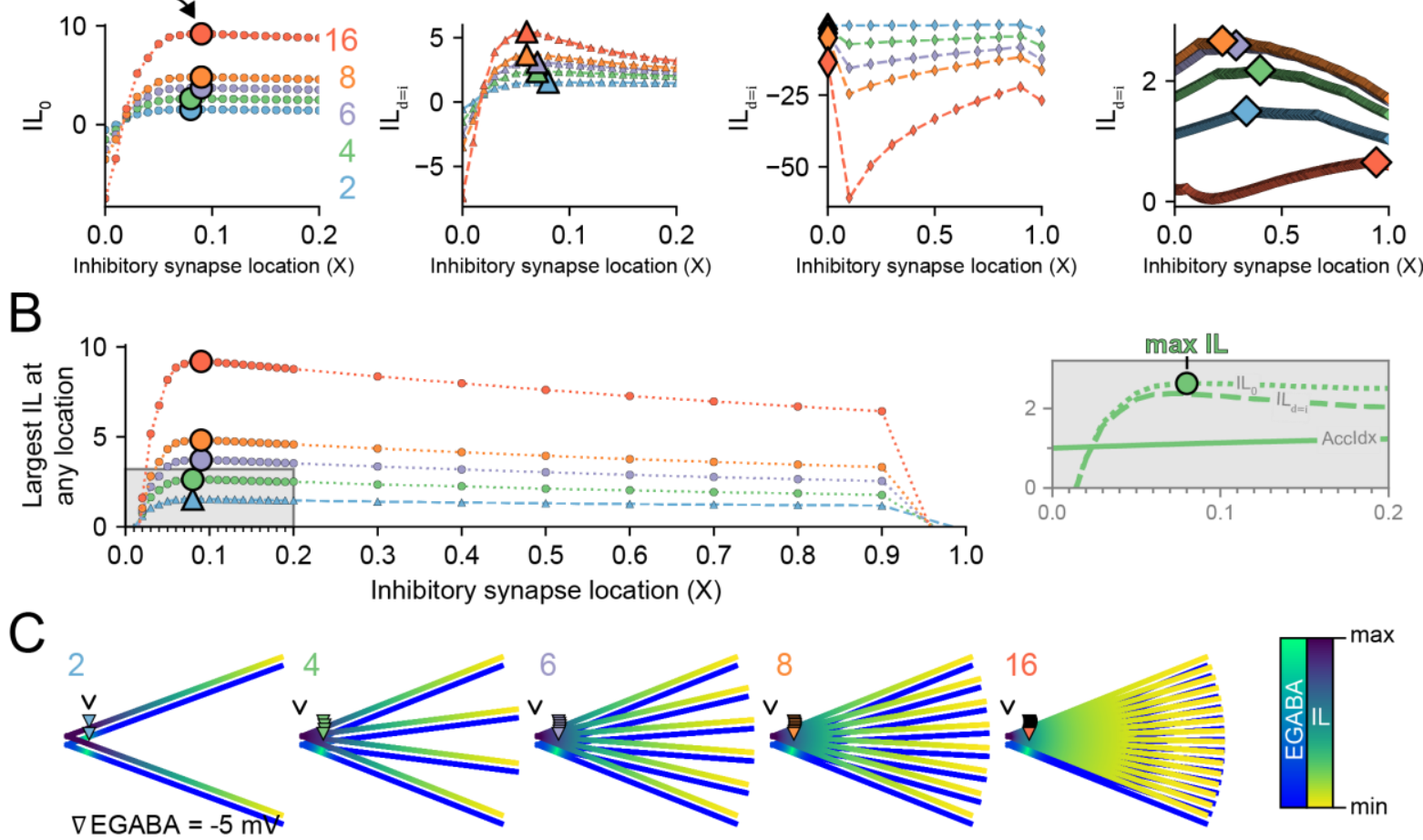

Figure 7 The optimal placement of inhibitory synapses to maximise the suppression of dendritic excitability.

Given the same number of inhibitory synapses as dendritic branches we determined their optimal placeent for different distribution strategies. (A) Left plots, for the "Tree" distribution (where each branch has a single inhibitory synapse at location i, example inset), the IL was measured (d) at the junction (ILo) and at the inhibitory synapses themselves $\left(\mathrm{IL}_{\mathrm{d}=\mathrm{i}}\right)$. Due to $\mathrm{Cl}^{-}$loading, the maximum $\mathrm{IL}$ at the junction $(\mathrm{IL})$, large marker, occurs when inhibitory synapses are a short distance away from the junction $(0.08$ to $0.09 \mathrm{X})$. This inhibitory synapse location is farther from the junction as the number of branches and synapses increases. In constrast, dendrites with more branches generate maximum $I L_{d=i}$ when the inhibitory synapses are located closer to the junction $(0.06$ to $0.08 \mathrm{X})$ as more branches mean that there are more avenues for diffusion to ameliorate deleterious [ $\left.\mathrm{Cl}^{-}\right] \mathrm{i}$ loading. Second from right plot, Inhibitory synapses placed in the "Focal" distribution (all concentrated at one spot) result in substantial $\mathrm{Cl}^{-}$ loading over $500 \mathrm{~ms}$ and therefore have an excitatory effect $(\mathrm{IL}<0)$. Right plot, $\mathrm{I} \mathrm{L}_{\mathrm{d}=\mathrm{i}}$ for each inhibitory synapse in "Branch" distributions where inhibitory synapses are placed with even spacing along a single branch. (B) The overall largest IL at any location on the dendritic tree is plotted for all varied synapse locations using the "Tree" distribution. The optimal location for inhibitory synapses to create the largest depression of dendritic excitability is $\approx 0.08 \mathrm{X}$ and encircling a junction. For 2 branches (blue), the overall maximum IL is at $\mathrm{i}$ itself; but additional branches have their maximum IL at the junction $\left(\mathrm{IL}_{0}\right)$. This location optimises the cumulative voltage-conductance inhibitory effect of the inhibitory synapses while reducing the pooling of $\mathrm{Cl}^{-}$loading via the synapses themselves. Inset, a dendrite with 4 branches and 4 synapses had its maximum IL when the inhibitory synapses were placed at $0.08 \mathrm{X}$ and IL was measured at the junction $\left(I \mathrm{~L}_{0}\right)$. The $I \mathrm{~L}_{\mathrm{d}=\mathrm{i}}$ and the accumulation index $\left(\right.$ Accldx $\left.=I \mathrm{~L}_{0} / \mathrm{IL}_{\mathrm{d}=\mathrm{i}}\right)$ are also shown for comparison. (C) EGABA and IL heatmaps with the optimal inhibitory synaptic placements (downward triangles) and the location for dampening dendritic excitability the most (' $v$ ') for 2 (blue), 4 (green), 6 (purple), 8 (orange), and 16 (red) inhibitory synapses and branches. 
bioRxiv preprint doi: https://doi org/10.1101/2021.12.07 471404; this version posted December 8,2021 . The copyright holder for this preprint (which was not certified by peer review) is the author/funder, who has granted bioRxiv a license to display the preprint in perpetuity. It is made available under aCC-BY 4.0 International license.

List of Abbreviations

\section{LIST OF ABBREVIATIONS}

Table 1: Symbols, constants, parameters, and variables

\begin{tabular}{|c|c|}
\hline & Description \\
\hline \multicolumn{2}{|l|}{ Symbols } \\
\hline $\mathrm{C}$ & Coulombs unit \\
\hline $\mathrm{Ca}^{2+}$ & Calcium ions \\
\hline $\mathrm{Cl}^{-}$ & Chloride ions \\
\hline $\mathrm{d}$ & Location of input current, in electrotonic units \\
\hline$\Delta$ & Delta, colloquially meaning difference between or change in something \\
\hline $\mathrm{E}$ & $\begin{array}{l}\text { Reversal potential, the value of which there is no net flow of current for that } \\
\text { transmembrane channel or ion species }\end{array}$ \\
\hline$g_{G A B A}$ & Time-varying conductance for $G A B A_{A} R$ \\
\hline GABA & $\gamma$-aminobutyric acid, the neurotransmitter released by interneurons \\
\hline $\mathrm{GABA}_{A} \mathrm{R}$ & $\begin{array}{l}\text { GABA type } A \text { receptor that mediates fast inhibitory synaptic transmission } \\
\text { when GABA is bound }\end{array}$ \\
\hline $\mathrm{GABA}_{\mathrm{B}} \mathrm{R}$ & $\begin{array}{l}\text { GABA type } B \text { receptor that mediates slow inhibitory synaptic transmission } \\
\text { when GABA is bound }\end{array}$ \\
\hline Glutamate & $\begin{array}{l}\text { Primary neurotransmitter released by pyramidal cells in cortex and } \\
\text { hippocampus }\end{array}$ \\
\hline $\mathrm{HCO}_{3}^{-}$ & Bicarbonate ions \\
\hline i & Location of inhibitory synaptic input, in electrotonic units \\
\hline$I$ & Current in amperes (A). Inward current is negative by convention \\
\hline$I_{C l^{-}}$ & Chloride ion current through a channel \\
\hline $\mathrm{I}_{\mathrm{HCO}}^{-}$ & Bicarbonate ion current through a channel \\
\hline$I_{G A B A}$ & Total current through $\mathrm{GABA}_{A} \mathrm{R}$ \\
\hline $\begin{array}{l}\mathrm{IL} \\
\mathrm{or} I \mathrm{i} \\
\mathrm{d}\end{array}$ & $\begin{array}{l}\text { Inhibitory Level. The impact that an inhibitory synapse at location i would } \\
\text { have on an input current at location } \mathrm{d} \text {. i and d are typically omitted whereby }\end{array}$ \\
\hline & $\mathrm{i}$ is fixed and $\mathrm{d}$ is varied. Defined as $\frac{V_{d}-V_{d}^{i}}{V_{d}}$ (see Variables). \\
\hline $\mathrm{IL}_{0}$ & Inhibitory Level at the junction of multiple dendritic branches \\
\hline$I L_{d=i}$ & Inhibitory Level at the inhibitory synapse i \\
\hline IL stat & Inhibitory Level determined with static chloride \\
\hline $\mathrm{IL}_{\text {dyn }}$ & Inhibitory Level determined with dynamic chloride \\
\hline $\mathrm{K}^{+}$ & Potassium ion \\
\hline KCC2 & Type 2 potassium-chloride cotransporter \\
\hline $\mathrm{Mg}^{2+}$ & Magnesium ion \\
\hline $\mathrm{Na}^{+}$ & Sodium ion \\
\hline NKCC1 & Type 1 sodium potassium chloride cotransporter \\
\hline NMDA & $\begin{array}{l}\mathrm{N} \text {-methyl-D-aspartate, which selectively activates the NMDA receptor, a } \\
\text { mediator of slow excitatory synaptic transmission when glutamate is bound }\end{array}$ \\
\hline Vol & Volume of neuronal compartment \\
\hline $\mathrm{X}$ & $\begin{array}{l}\text { Electrotonic unit. Proportion of the space constant, which is a measure of } \\
\text { how far voltage will travel within a neuronal compartment as it attenuates } \\
\text { with distance }\end{array}$ \\
\hline $\begin{array}{l}\text { Constants } \\
\text { F }\end{array}$ & $\begin{array}{l}\text { Value } \\
96485 \\
\mathrm{~s} \cdot \mathrm{A} \cdot \mathrm{mol}^{-1}\end{array}$ \\
\hline
\end{tabular}


List of Abbreviations

\begin{tabular}{|c|c|c|}
\hline $\mathrm{R}$ & $\begin{array}{l}\text { Ideal gas constant } \\
\text { Absolute temperature }\left(=37^{\circ} \mathrm{C}\right)\end{array}$ & $\begin{array}{l}8.3145 \\
\mathrm{~J} \cdot \mathrm{K}^{-1} \cdot \mathrm{mol}^{-1} \\
310.15 \mathrm{~K}\end{array}$ \\
\hline Parameters & & Default Value \\
\hline$\left[\mathrm{Cl}^{-}\right]_{\mathrm{o}}$ & Extracellular chloride concentration & $135 \mathrm{mM}$ \\
\hline$\left[\mathrm{HCO}_{3}^{-}\right]_{0}$ & Extracellular bicarbonate concentration & $23 \mathrm{mM}$ \\
\hline$\left[\mathrm{HCO}_{3}^{-}\right]_{\mathrm{i}}$ & Intracellular bicarbonate concentration & $12 \mathrm{mM}$ \\
\hline$\alpha_{\mathrm{GABA}}$ & $\mathrm{GABA}_{A}$ receptor binding rate [54] & $5 \mathrm{mM}^{-1} \mathrm{~ms}^{-1}$ \\
\hline$\beta_{G A B A}$ & $\mathrm{GABA}_{\mathrm{A}}$ receptor unbinding rate [54] & $0.18 \mathrm{~ms}^{-1}$ \\
\hline$D_{C l^{-}}$ & Chloride diffusion constant [55] & $2.03 \mu \mathrm{m}^{2} \mathrm{~ms}^{-1}$ \\
\hline$E_{\text {leak }}$ or $V_{\text {rest }}$ & $\begin{array}{l}\text { The resting membrane potential or reversal potential for } \\
\text { the current leak channel; the voltage of the neuron if there } \\
\text { was no external current or synaptic input }\end{array}$ & See $V_{m}$ \\
\hline gGABAmax & Maximum conductance for a $\mathrm{GABA}_{\mathrm{A}}$ receptor & $1 \mathrm{nS}$ \\
\hline gleak & Conductance for the leak current & $0.00021 \mu S$ \\
\hline $\mathrm{P}_{\text {KCC2 }}$ & Pump strength of $\mathrm{KCC} 2$ to extrude $\mathrm{Cl}^{-}$along with $\mathrm{K}^{+}$[26] & $\begin{array}{l}1.9297 \times 10^{-5} \\
\mathrm{~mA} \mathrm{mM} \mathrm{mM}^{-2} \mathrm{~cm}^{-2}\end{array}$ \\
\hline Variables & & Initial Value \\
\hline$\left[\mathrm{Cl}^{-}\right]_{\mathrm{i}}$ & Intracellular chloride ion concentration & $4.25 \mathrm{mM}$ \\
\hline $\mathrm{ECl}^{-}$ & $\begin{array}{l}\text { Reversal potential for chloride ions at a transmembrane } \\
\text { channel (values are for a } G A B A_{A} R \text { ) }\end{array}$ & $\begin{array}{l}-92.42 \mathrm{mV} \\
-88.00 \mathrm{mV}\end{array}$ \\
\hline EGABA & $\begin{array}{l}\text { Reversal potential for a } \mathrm{GABA} A \mathrm{R} \text {, unless type otherwise } \\
\text { specified, e.g. } E_{G A B A_{B}}\end{array}$ & $\begin{array}{l}-77.41 \mathrm{mV} \\
-74.00 \mathrm{mV}\end{array}$ \\
\hline$\nabla E G A B A$ & $\begin{array}{l}\text { The EGABA relative to the resting membrane potential, } \\
V_{m}(t=0)-E G A B A\end{array}$ & $-5 m V$ for $I L_{d y n}$ \\
\hline$V_{m}$ & Membrane potential (voltage) & $-65.00 \mathrm{mV}$ \\
\hline $\mathrm{Vd}$ & $\begin{array}{l}\text { The integral of } V_{m} \text { with respect to resting } V_{m} \text { at location } d \text {. } \\
\int_{t}^{t+\Delta t} V_{m}(t)-V_{m}(t=0) d t\end{array}$ & $0 \mathrm{mV}$ \\
\hline
\end{tabular}


bioRxiv preprint doi: https://doi.org/10.1101/2021.12.07.471404; this version posted December 8,2021 . The copyright holder for this preprint (which was not certified by peer review) is the author/funder, who has granted bioRxiv a license to display the preprint in perpetuity. It is made available under aCC-BY 4.0 International license.

\section{REFERENCES}

1. Kalisman N, Silberberg G, Markram H. Deriving physical connectivity from neuronal morphology. Biol Cybern. 2003;88: 210-218. doi:10.1007/s00422-002-0377-3

2. Perin R, Berger TK, Markram H. A synaptic organizing principle for cortical neuronal groups. Proc Natl Acad Sci U S A. 2011;108: 5419-5424. doi:10.1073/pnas.1016051108

3. Markram H, Muller E, Ramaswamy S, Reimann MW, Abdellah M, Sanchez CA, et al. Reconstruction and simulation of neocortical microcircuitry. Cell. 2015;163: 456-492. doi:10.1016/j.cell.2015.09.029

4. London M, Häusser M. Dendritic computation. Annu Rev Neurosci. 2005;28: 503-532. doi:10.1146/annurev.neuro.28.061604.135703

5. Branco $\mathrm{T}$, Hausser $\mathrm{M}$. The single dendritic branch as a fundamental functional unit in the nervous system. Curr Opin Neurobiol. 2010;20: 494-502. doi:10.1016/j.conb.2010.07.009

6. Spruston N, Stuart G, Häusser M. Dendrites. Third. Spruston N, Stuart G, Häusser M, editors. Dendrites. Oxford, UK: Oxford University Press; 2016. doi:10.1093/acprof:oso/9780198745273.001.0001

7. Silver RA. Neuronal arithmetic. Nat Rev Neurosci. 2010;11: 474-489. doi:10.1038/nrn2864

8. Almog M, Korngreen A. Is realistic neuronal modeling realistic? J Neurophysiol. 2016;116: 2180-2209. doi:10.1152/jn.00360.2016

9. Kaifosh P, Losonczy A. Mnemonic functions for nonlinear dendritic integration in hippocampal pyramidal circuits. Neuron. 2016;90: 622-634. doi:10.1016/j.neuron.2016.03.019

10. Gidon A, Zolnik TA, Fidzinski P, Bolduan F, Papoutsi A, Poirazi P, et al. Dendritic action potentials and computation in human layer 2/3 cortical neurons. Science (80- ). 2020;367: 83-87. doi:10.1126/science.aax6239

11. Jadi M, Polsky A, Schiller J, Mel BW. Location-dependent effects of inhibition on local spiking in pyramidal neuron dendrites. Gutkin BS, editor. PLoS Comput Biol. 2012;8: e1002550. doi:10.1371/journal.pcbi.1002550

12. Lovett-Barron M, Turi GF, Kaifosh P, Lee PH, Bolze F, Sun X-H, et al. Regulation of neuronal input transformations by tunable dendritic inhibition. Nat Neurosci. 2012;15: 423-30, S1-3. doi:10.1038/nn.3024

13. Guerguiev J, Lillicrap TP, Richards BA. Towards deep learning with segregated dendrites. Elife. 2017;6: e22901. doi:10.7554/eLife.22901

14. Rall W. Electrophysiology of a Dendritic Neuron Model. Biophys J. 1962;2: 145-167. doi:10.1016/S00063495(62)86953-7

15. Rall W. Branching dendritic trees and motoneuron membrane resistivity. Exp Neurol. 1959;1: 491-527. doi:10.1016/0014-4886(59)90046-9

16. Koch C, Poggio T, Torre V. Nonlinear interactions in a dendritic tree: localization, timing, and role in information processing. Proc Natl Acad Sci. 1983. doi:10.1073/pnas.80.9.2799

17. Rinzel J, Rall W. Transient response in a dendritic neuron model for current injected at one branch. Biophys J. 1974;14: 759-790. doi:10.1016/S0006-3495(74)85948-5

18. Rall W, Rinzel J. Branch input resistance and steady attenuation for input to one branch of a dendritic neuron model. Biophys J. 1973;13: 648-688. doi:10.1016/S0006-3495(73)86014-X

19. Rall W. Theoretical significance of dendritic trees for neuronal input-output relations. In: Reiss RF, editor. Neural Theory and Modeling,. Palo Alto: Stanford University Press; 1964. doi:10.7551/mitpress/6743.003.0015

20. Spruston N, Stuart G, Häusser M. Principles of Dendritic Integration. 3rd ed. In: Stuart G, Spruston N, Häusser M, editors. Principles of dendritic integration. 3rd ed. Oxford, UK: Oxford University Press; 2016. 
bioRxiv preprint doi: https://doi.org/10.1101/2021.12.07.471404; this version posted December $8,2021$. The copyright holder for this preprint (which was not certified by peer review) is the author/funder, who has granted bioRxiv a license to display the preprint in perpetuity. It is made available under aCC-BY 4.0 International license.

\section{References}

pp. 351-398. doi:10.1093/acprof:oso/9780198745273.003.0012

21. Gidon A, Segev I. Principles governing the operation of synaptic inhibition in dendrites. Neuron. 2012;75: 330-341. doi:10.1016/j.neuron.2012.05.015

22. Häusser M, Mel B. Dendrites: bug or feature? Curr Opin Neurobiol. 2003;13: 372-383. doi:10.1016/S0959-4388(03)00075-8

23. Poirazi P, Brannon T, Mel BW. Pyramidal neuron as two-layer neural network. Neuron. 2003;37: 989999. doi:10.1016/S0896-6273(03)00149-1

24. Trevelyan AJ, Watkinson O. Does inhibition balance excitation in neocortex? Prog Biophys Mol Biol. 2005;87: 109-143. doi:10.1016/j.pbiomolbio.2004.06.008

25. Pouille F, Watkinson O, Scanziani M, Trevelyan AJ. The contribution of synaptic location to inhibitory gain control in pyramidal cells. Physiol Rep. 2013;1: 1-9. doi:10.1002/phy2.67

26. Currin CB, Trevelyan AJ, Akerman CJ, Raimondo J V. Chloride dynamics alter the input-output properties of neurons. Berry H, editor. PLOS Comput Biol. 2020;16: e1007932. doi:10.1371/journal.pcbi.1007932

27. Doyon N, Prescott S a, Castonguay A, Godin AG, Kröger H, De Koninck Y. Efficacy of synaptic inhibition depends on multiple, dynamically interacting mechanisms implicated in chloride homeostasis. PLoS Comput Biol. 2011;7: 1-22. doi:10.1371/journal.pcbi.1002149

28. Kaila K, Voipio J. Postsynaptic fall in intracellular $\mathrm{pH}$ induced by GABA-activated bicarbonate conductance. Nature. 1987.

29. Raimondo J V, Richards BA, Woodin MA. Neuronal chloride and excitability — the big impact of small changes. Curr Opin Neurobiol. 2017;43: 35-42. doi:http://dx.doi.org/10.1016/j.conb.2016.11.012

30. Ellender TJ, Raimondo J V., Irkle A, Lamsa KP, Akerman CJ. Excitatory effects of parvalbuminexpressing interneurons maintain hippocampal epileptiform activity via synchronous afterdischarges. $J$ Neurosci. 2014;34: 15208-15222. doi:10.1523/JNEUROSCI.1747-14.2014

31. Lewin N, Aksay E, Clancy CEE. Computational modeling reveals dendritic origins of GABA(A)-mediated rxcitation in CA1 pyramidal neurons. PLoS One. 2012;7: 1-17. doi:10.1371/journal.pone.0047250

32. Jedlicka P, Deller T, Gutkin BS, Backus KH. Activity-dependent intracellular chloride accumulation and diffusion controls $\mathrm{GABA}(\mathrm{A})$ receptor-mediated synaptic transmission. Hippocampus. 2011;21: 885-98. doi:10.1002/hipo.20804

33. Staley KJ, Proctor WR. Modulation of mammalian dendritic GABA(A) receptor function by the kinetics of Cl- and HCO3- transport. J Physiol. 1999;519: 693-712. doi:PHY_9331 [pii]

34. Rall W. Theoretical Significance of Dendritic Trees for Neuronal Input-Output Relations (1964). In: Segev I, Rinzel J, Shepherd GM, editors. The Theoretical Foundation of Dendritic Function. Palo Alto, CA, CA: The MIT Press; 2003. doi:10.7551/mitpress/6743.003.0015

35. Holmes WR. Space (Length) Constant, Lambda, in Neuronal Signaling. In: Jaeger D, Jung R, editors Encyclopedia of Computational Neuroscience. New York, NY: Springer New York; 2014. pp. 1-2. doi:10.1007/978-1-4614-7320-6_36-1

36. Carnevale NT, Hines ML. The NEURON Book. Cambridge: Cambridge University Press; 2006. doi:10.1017/CBO9780511541612

37. Hines ML, Davison AP, Muller E. NEURON and Python. Front Neuroinform. 2009;3: 12. doi:10.3389/neuro.11.001.2009

38. Koch C, Douglas R, Wehmeier U. Visibility of synaptically induced conductance changes: Theory and simulations of anatomically characterized cortical pyramidal cells. J Neurosci. 1990;10: 1728-1744. doi:10.1523/jneurosci.10-06-01728.1990

39. Megías M, Emri Z, Freund TF, Gulyás a I. Total number and distribution of inhibitory and excitatory synapses on hippocampal CA1 pyramidal cells. Neuroscience. 2001;102: 527-540. doi:S03064522(00)00496-6 [pii]

40. Raimondo J V, Markram H, Akerman CJ. Short-term ionic plasticity at GABAergic synapses. Front 
bioRxiv preprint doi: https://doi.org/10.1101/2021.12.07.471404; this version posted December $8,2021$. The copyright holder for this preprint (which was not certified by peer review) is the author/funder, who has granted bioRxiv a license to display the preprint in perpetuity. It is made available under aCC-BY 4.0 International license.

\section{References}

Synaptic Neurosci. 2012;4: 5. doi:10.3389/fnsyn.2012.00005

41. Major G, Larkum ME, Schiller J. Active properties of neocortical pyramidal neuron dendrites. Annu Rev Neurosci. 2013;36: 1-24. doi:10.1146/annurev-neuro-062111-150343

42. Stuart GJ, Spruston N. Dendritic integration: 60 years of progress. Nat Neurosci. 2015;18: 1713-1721. doi:10.1038/nn.4157

43. Kastellakis G, Poirazi P. Synaptic clustering and memory formation. Front Mol Neurosci. 2019;12: 300. doi:10.3389/fnmol.2019.00300

44. Chen JL, Villa KL, Cha JW, So PTC, Kubota Y, Nedivi E. Clustered dynamics of inhibitory synapses and dendritic spines in the adult neocortex. Neuron. 2012;74: 361-373. doi:10.1016/j.neuron.2012.02.030

45. Ohme M, Schierwagen A. An equivalent cable model for neuronal trees with active membrane. Biol Cybern. 1998;78: 227-243. doi:10.1007/s004220050429

46. DeFelipe J, Fariñas I. The pyramidal neuron of the cerebral cortex: Morphological and chemical characteristics of the synaptic inputs. Prog Neurobiol. 1992;39: 563-607. doi:10.1016/03010082(92)90015-7

47. Merchan-Pérez A. Counting synapses using FIB/SEM microscopy: A true revolution for ultrastructural volume reconstruction. Front Neuroanat. 2009;3: 18. doi:10.3389/neuro.05.018.2009

48. Bloss EB, Cembrowski MS, Karsh B, Colonell J, Fetter RD, Spruston N. Structured dendritic inhibition supports branch-selective integration in CA1 pyramidal cells. Neuron. 2016;89: 1016-1030. doi:10.1016/j.neuron.2016.01.029

49. Hao J, Wang X, Dan Y, Poo M, Zhang X. An arithmetic rule for spatial summation of excitatory and inhibitory inputs in pyramidal neurons. Proc Natl Acad Sci U S A. 2009;106: 21906-11. doi:10.1073/pnas.0912022106

50. Larkum ME, Zhu JJ, Sakmann B. A new cellular mechanism for coupling inputs arriving at different cortical layers. Nature. 1999;398: 338-341. doi:10.1038/18686

51. Graham RT, Parrish RR, Alberio L, Johnson EL, Owens LJ, Trevelyan AJ. Synergistic positive feedback underlying seizure initiation. bioRxiv. 2021; 2021.02.28.433224. doi:10.1101/2021.02.28.433224

52. Davie JT, Kole MHP, Letzkus JJ, Rancz EA, Spruston N, Stuart GJ, et al. Dendritic patch-clamp recording. Nat Protoc. 2006;1: 1235-47. doi:10.1038/nprot.2006.164

53. Hayama T, Noguchi J, Watanabe S, Takahashi N, Hayashi-Takagi A, Ellis-Davies GCR, et al. GABA promotes the competitive selection of dendritic spines by controlling local Ca2+ signaling. Nat Neurosci. 2013;16: 1409-16. doi:10.1038/nn.3496

54. Destexhe A, Mainen ZF, Sejnowski TJ. Kinetic models of synaptic transmission: From ions to networks. Methods Neural Model from lons to Networks. 1998; 1-25.

55. Hille B. Ion Channels of Excitable Membranes. 3rd ed. Sunderland, MA: Sinauer Associates, Inc.; 2001. 